\title{
Synthesis
}

\section{Toward Integrated Analysis of Human Impacts on Forest Biodiversity: Lessons from Latin America}

\author{
$\underline{\text { Adrian C. Newton }}^{1}$, Luis Cayuela $^{2}$, Cristian Echeverría $^{3}, \underline{\text { Juan J. Armesto }}^{4}, \underline{\text { Rafael F. Del Castillo }}^{5}$, \\ Duncan Golicher $^{6}$, Davide Geneletti $^{7}$, Mario Gonzalez-Espinosa ${ }^{8}$, Andreas Huth $^{9}$, \\ Fabiola López-Barrera $^{10}$, Lucio Malizia $^{11}$, Robert Manson ${ }^{10}$, Andrea Premoli ${ }^{12}$, \\ $\underline{\text { Neptali Ramírez-Marcial }}^{8}, \underline{\text { José-Maria Rey Benayas }}^{13}{ }^{\text {Nodja }}$ Rüger $^{9}{ }^{9}$ Cecilia Smith-Ramírez $^{4}$, and \\ Guadalupe Williams-Linera ${ }^{10}$
}

\begin{abstract}
Although sustainable forest management (SFM) has been widely adopted as a policy and management goal, high rates of forest loss and degradation are still occurring in many areas. Human activities such as logging, livestock husbandry, crop cultivation, infrastructural development, and use of fire are causing widespread loss of biodiversity, restricting progress toward SFM. In such situations, there is an urgent need for tools that can provide an integrated assessment of human impacts on forest biodiversity and that can support decision making related to forest use. This paper summarizes the experience gained by an international collaborative research effort spanning more than a decade, focusing on the tropical montane forests of Mexico and the temperate rain forests of southern South America, both of which are global conservation priorities. The lessons learned from this research are identified, specifically in relation to developing an integrated modeling framework for achieving SFM. Experience has highlighted a number of challenges that need to be overcome in such areas, including the lack of information regarding ecological processes and species characteristics and a lack of forest inventory data, which hinders model parameterization. Quantitative models are poorly developed for some ecological phenomena, such as edge effects and genetic diversity, limiting model integration. Establishment of participatory approaches to forest management is difficult, as a supportive institutional and policy environment is often lacking. However, experience to date suggests that the modeling toolkit approach suggested by Sturvetant et al. (2008) could be of value in such areas. Suggestions are made regarding desirable elements of such a toolkit to support participatory-research approaches in domains characterized by high uncertainty, including Bayesian Belief Networks, spatial multi-criteria analysis, and scenario planning.
\end{abstract}

Key Words: biodiversity conservation; environmental modeling; landscape ecology; Latin America; spatial analysis; sustainable forest management

\section{INTRODUCTION}

Over the past two decades, sustainable forest management (SFM) has become a global environmental issue, reflecting widespread concern about high rates of forest loss and degradation. This is illustrated by the development of international policy initiatives such as the Convention on Biological Diversity (CBD), the Forest Principles of Agenda 21, the United Nations Forum on Forests (UNFF), and the many processes developing criteria and indicators for SFM (Newton 2007a, Nussbaum and Simula 2005, Wiersum 1995). Despite these initiatives, progress toward SFM has been very limited (Rametsteiner and Simula 2003), and high rates of forest loss and degradation are still being reported in many areas (Food and Agriculture Organization (FAO) 2006).

SFM can be considered as a form of integrated landuse planning, which requires integration of social, economic, and environmental information (Nussbaum

${ }^{1}$ Centre for Conservation Ecology and Environmental Change, Bournemouth University, ${ }^{2}$ Departamento de Ecología, Universidad de Alcalá, ${ }^{3}$ Universidad de Concepción, ${ }^{4}$ Pontificia Universidad Católica de Chile, ${ }^{5}$ CIIDIR, Instituto Politécnico Nacional, ${ }^{6}$ El Colegio de la Frontera Sur, ${ }^{7}$ Università degli Studi di Trento, ${ }^{8}$ ECOSUR, ${ }^{9}$ UFZ, ${ }^{10}$ Instituto de Ecología, ${ }^{11}$ Fundación Proyungas, ${ }^{12}$ Universidad Nacional del Comahue, ${ }^{13}$ Universidad de Alcalá 
and Simula 2005). Sturtevant et al. (2007) note that to achieve SFM, tools for supporting strategic landscape planning are required that address specific questions and use local information, while making use of existing models and techniques. As the socioeconomic and environmental relationships associated with SFM are complex, no single model or tool is likely to suffice. Consequently Sturtevant et al. (2007) propose a "toolkit" approach, involving selection of a range of pre-existing models from a model toolkit, each appropriate for use at a particular scale and domain. Implementation of this approach presents the challenge of integrating the different information produced by such models, across a range of scales. Sturtevant et al. (2007) suggest that this may be achieved by the use of "meta-models" (defined as "models derived from other models"; Urban et al. 1999), in which models are loosely coupled by using output from one as input to another.

The toolkit approach arose from studies of boreal forested ecosystems in North America (e.g., Fall et al. 2004, Sturtevant et al. 2004, Gustafson et al. 2006). This raises the question of whether such an approach might be of value to forests in other areas with very different characteristics. Many developing countries are currently experiencing high rates of forest loss and degradation as a result of over-exploitation and conversion of forest to other land uses (Newton 2007b, FAO 2006, Millennium Ecosystem Assessment (MEA) 2005). In such circumstances, SFM may appear to be a very distant prospect, with timber effectively being mined rather than sustainably harvested. Land-use planning may be very limited or even entirely lacking, reflecting limited institutional capacity, and a lack of an appropriate legislative framework, financial resources, and political will. Use of scientific information or decision-support tools of any kind in such situations is currently rare. These conditions prevail in many forest areas of global conservation importance, such as the biodiversity hotspots identified by Myers et al. (2000). In such areas, tools and approaches for supporting implementation of SFM are urgently required.

This paper summarizes the experience gained by an international collaborative research effort spanning more than a decade, which focused on the tropical montane forests of Mexico and the temperate rain forests of southern South America. These forest types have previously been neglected by researchers, despite their global conservation importance. Both types are characterized by high species richness and endemism, and are consequently recognized as global conservation priorities, being listed as biodiversity "hotspots" (Myers et al. 2000) and as priority ecoregions (Dinerstein et al. 1995). The objective of the research was to investigate the impacts of human activities on forest biodiversity, with the aim of informing the development of SFM approaches. Research results are summarized by Newton (2007b). The current paper identifies the lessons learned from this research, specifically in relation to developing an integrated modeling framework for achieving SFM. Reference is also made to an ongoing research initiative in the same geographic areas, focusing on restoration of dryland forests (Newton 2008a), in which many of the same partners are involved. In each case, research has primarily focused on forest areas that are being subjected to some form of human use, namely those areas lying outside protected area networks. As noted by Lindenmayer and Franklin (2002), the future conservation of forest biodiversity will depend largely on how such unprotected forest areas are managed.

\section{METHODS}

\section{Study Areas}

Research was undertaken in Mexico, in the states of Veracruz, Oaxaca, and Chiapas, and in the southern cone of South America (Chile and Argentina) (Appendix 1). Despite differing in their floristic composition, moist forests in these areas are structurally similar, including both coniferous and broadleaved tree species. Climatic conditions are also broadly similar, being humid (mean annual rainfall $>2000 \mathrm{~mm}$ ) and temperate in character (mean annual temperatures $10-20^{\circ} \mathrm{C}$ ). In Mexico, upper montane forests cover less than $1 \%$ of the land surface of the country, but contain about $12 \%$ of the country's 30000 plant species, some $30 \%$ of which are endemic (Rzedowski 1996). The temperate rain forests of southern South America ("Valdivian" forests of Chile and Argentina) are home to more than 900 vascular plant species, including 60 tree species, over $90 \%$ of which are endemic (Arroyo et al. 1995).

Forests in each of the study areas play a major role in supporting the livelihoods of rural communities, but face similar pressures resulting from human 
activities, including clearance for agriculture, browsing by livestock, human-set fires, timber logging, and fuelwood extraction. Typically, current land cover is a mosaic of remnant patches of degraded native primary forest, secondary forest, plantations, pastures, agricultural crops, and human settlements. In Chiapas and Oaxaca, land tenure is generally communal, whereas in the other study areas, most land is privately owned. Further details of the study areas are provided in Appendix 1. It should be noted that progress toward sustainable harvesting of forest products from natural forests has been very limited in all of the study areas.

\section{Analytical Framework}

A conceptual model was developed at the outset of the research, to provide an analytical framework for the research activities and to support integration of results. The model is based on the assumption that the conservation of biodiversity depends on the maintenance of key ecological processes, which determine the composition and structure of biological communities and patterns of genetic variation (Fig. 1). In areas subjected to human use, the main factor determining the scope for biodiversity conservation is the extent to which these processes are influenced by patterns of land use. Areas where deforestation is occurring at a high rate are generally characterized by conversion of forest to agricultural land uses, such as crop cultivation and grazing, often in addition to logging and the use of fire. Clearance of forest for agriculture leads to a decline in forest area and fragmentation of forest habitat. Remnant patches of forest may be further degraded by extraction of forest products, and by alteration of environmental conditions in newly created forest edges. Human activities may have impacts both at the landscape scale and the scale of individual forest patches, influencing habitat characteristics and ecological processes at these different scales (Fig. 1).

Research activities were organized as a series of themes, each addressing an individual aspect of the overall objective of SFM (Fig. 2). Research actions focused primarily on conservation of forest biodiversity as a key component of sustainable management approaches, but to date have not examined the full range of environmental and socioeconomic aspects that SFM encompasses. Integration of research results required information flow between research themes, and was achieved using a variety of different modeling approaches (Table 1). Research outputs were also designed to support the development and implementation of policies relating to SFM, through the development of decision-support tools and management recommendations. Details of the research methods adopted for each of these themes are presented below, with particular reference to the modeling tools employed.

\section{FOREST LOSS AND FRAGMENTATION}

The pattern of forest loss was examined in four study areas by producing maps of forest cover from Landsat satellite images and aerial photographs, using a geographic information system (GIS). Two of these study areas are located in Mexico (Chiapas and Veracruz) and two in Chile (Rio MauleCobquecura, "Maule"; and Los Muermos-Ancud, "Muermos"). Forest maps were produced from images obtained at different times during the past three decades, which were classified using results from field surveys, and used to estimate annual deforestation rates (Cayuela et al. 2006a,c, Echeverría et al. 2006, 2007a). Landscape spatial indices were computed using FRAGSTATS (version 3.3) (McGarigal et al. 2002). Results indicated that substantial deforestation has occurred in each of the study areas in recent decades (Fig. 3; Cayuela et al. 2006a,c, Echeverría et al. 2006, 2007a). For example, in Chiapas, by 2000 forest area had declined to less than one-third of its value in 1975. Between 1975 and 1990, the forest loss rate was $1.5 \% \mathrm{yr}^{-1}$, whereas between 1990 and 2000, this rate increased to $6.1 \% \mathrm{yr}^{-1}$. In Maule, $67 \%$ of the native forest existing in 1975 had disappeared by 2000 , equivalent to an annual deforestation rate of $4.4 \% \mathrm{yr}^{-1}$. Most of the forest loss occurred in the period 1975-1990, at a deforestation rate of 5.0\% $\mathrm{yr}^{-1}$. In Muermos, approximately $23 \%$ of native forest present in 1976 had disappeared by 1999, at an annual forest loss of $1.1 \% \mathrm{yr}^{-1}$. In Veracruz, loss of native forest occurred at a rate of $2.0 \% \mathrm{yr}^{-1}$.

In each study area, deforestation was accompanied by substantial forest fragmentation (Cayuela et al. 2006a,c, Echeverría et al. 2006, 2007a,b). The mean size of forest patches declined progressively, displaying most rapid decline in Chiapas (Fig. 4a). This was accompanied by an increase in patch density, with rate of change again most pronounced in Chiapas (Fig. 4b). However, in Maule, patch 
Fig. 1. Schematic diagram indicating the hypothesized impacts of different human activities on biodiversity in fragmented forest landscapes. Human activities influence forest habitat characteristics at a range of scales, which in turn affect the key ecological processes influencing the different components of biodiversity.

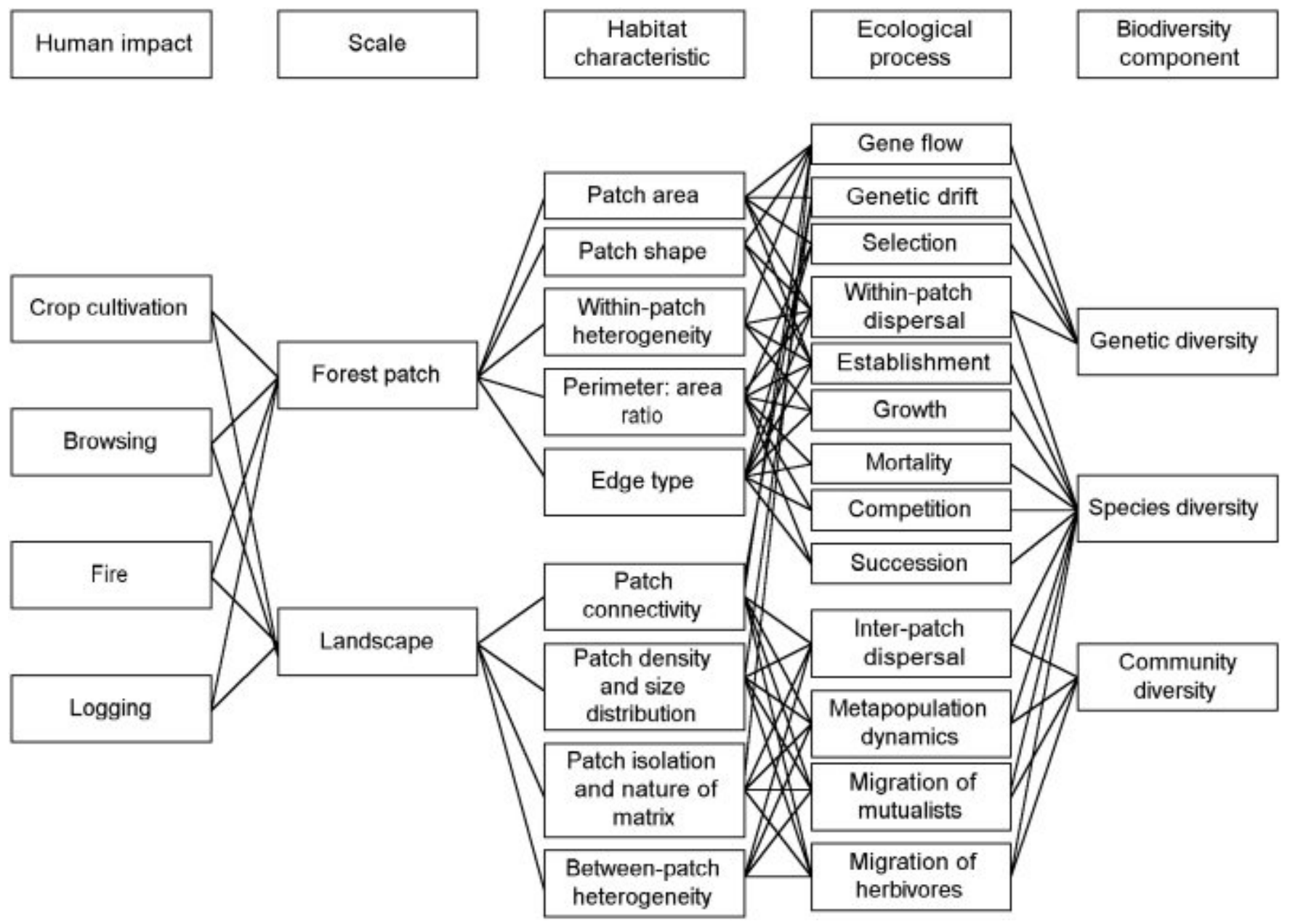

density declined during 1990-2000. This reflected the fact that deforestation had been so severe that little forest was left to be divided into smaller patches. In all study areas, these changes were associated with a decrease in the percentage of area accounted for by the largest patch, a decrease in total interior area of forest patches, and an increase in the isolation of forest patches.

Both forest loss and fragmentation were explored using statistical and rule-based modeling approaches, to examine the spatial dynamics of forest cover at the landscape scale and the potential influence of different drivers. For example, Echeverría et al. (2008) used both spatially explicit logistic regression and a GIS-based land-use change model (GEOMOD) to examine the pattern of forest loss and fragmentation in southern Chile during the past three decades. Both modeling approaches showed consistent and complementary results with respect to the drivers that were most related to deforestation. Results indicated that between 1976 and 1999, forest loss has occurred mainly from the edges of small fragments situated on gentle slopes $\left(<10^{\circ}\right)$ and located far away from rivers, the latter finding relating to the fact that clearance of forests 
Fig. 2. Relationship between research themes investigating the impacts of human activities on forest biodiversity in Latin America. The text boxes represent the main research themes implemented in the research projects described in the main text. Arrows represent information flow. The research themes addressed different impacts of human activities on different elements of forest biodiversity, together with selected response options, to inform the development of sustainable management approaches.

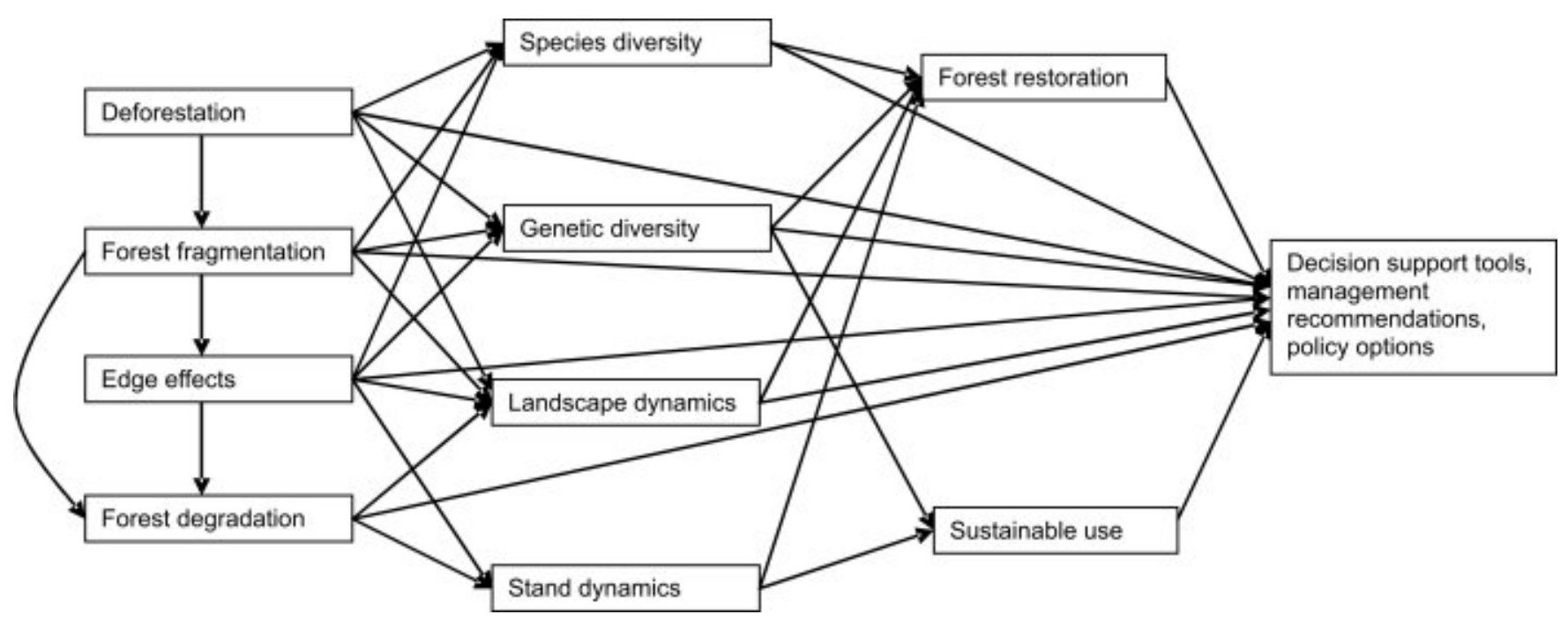

is legally prohibited in areas close to rivers or with high flood risk (Echeverría et al. 2008). GEOMOD was able to correctly classify $88 \%$ of grid cells based on decision rules relating to slope, distance to rivers, and a nearest-neighbor deforestation rule. These results indicated that forest logging and clearance for crops and pasture land are the main human activities associated with the changes in the spatial configuration of forest cover (Echeverría et al. 2008). Similarly, Wilson et al. (2005) used classification tree and regression analyses to analyze conversion of native forest in southern Chile to plantations of exotic species. Results indicated that significant variables associated with this conversion included soil type, slope, altitude, distance to roads, and distance to towns.

\section{EDGE EFFECTS}

The characteristics of habitat edges are influenced by patterns of land use surrounding forest fragments and can have a major impact on biodiversity by affecting ecological processes such as dispersal, establishment, survival, and growth (Harper et al. 2005). A large number of studies have examined such impacts, and have identified a wide variety of responses. Ries et al. (2004) and Harper et al. (2005) both present conceptual models of edge effects based on reviews of the results obtained by previous investigations. However, progress toward developing quantitative predictive models for edge effects has been limited to date.

We undertook 22 field-based studies comparing forest edge and forest interior habitats (Table 2, López-Barrera et al. 2007a). From the 34 response variables considered, 19 resulted in a positive edge effect (i.e., higher values of the response variable in the edge vs. forest), nine in a negative edge effect, and six recorded no edge effect. Edge effects were detected on a wide variety of processes, including seed rain, avian nest predation, seed germination, seed removal, and predation (Table 2). From all of the response variables tested in three different study regions, only tree seedling growth and survival exhibited consistent responses in all regions, displaying higher values in edges.

Our results were consistent with some hypotheses presented previously. For example, as predicted by Harper et al. (2005), we found that the magnitude 
Table 1. Modeling approaches associated with research themes. (See Fig. 2 for relationships between research themes and Appendix $\mathrm{X}$ for details of modeling approaches.)

\begin{tabular}{|c|c|c|}
\hline Research theme & Modeling approach & References \\
\hline Deforestation & $\begin{array}{l}\text { Statistical modeling (e.g., logistic } \\
\text { regression) }\end{array}$ & $\begin{array}{l}\text { Echeverría et al. (2007a,b), Wilson et } \\
\text { al. (2005), Cayuela et al. (2006a,c) }\end{array}$ \\
\hline Forest fragmentation & $\begin{array}{l}\text { Statistical modeling (e.g., logistic } \\
\text { regression) }\end{array}$ & $\begin{array}{l}\text { Echeverría et al. (2007a,b), Cayuela et } \\
\text { al. }(2006 b, d)\end{array}$ \\
\hline Edge effects & Statistical analysis, conceptual modeling & $\begin{array}{l}\text { López-Barrera et al. (2005, 2006, } \\
\text { 2007a,b), Guzmán-Guzmán and } \\
\text { Williams-Linera (2006). }\end{array}$ \\
\hline Forest degradation & Statistical modeling (regression) & $\begin{array}{l}\text { Newton et al. (2007), Echeverría et al. } \\
(2007 \text { a,b), Cayuela et al. }(2006 b, d)\end{array}$ \\
\hline Species diversity & Statistical modeling, SPARs & $\begin{array}{l}\text { Echeverría et al. (2007a,b), Rey } \\
\text { Benayas et al. (2007), Cayuela et al. } \\
(2006 b, d)\end{array}$ \\
\hline Genetic diversity & Statistical analysis and modeling & Premoli et al. (2007) \\
\hline $\begin{array}{l}\text { Landscape dynamics (including land- } \\
\text { use change and climate change } \\
\text { impacts) }\end{array}$ & $\begin{array}{l}\text { LANDIS II, GEOMOD, DOMAIN, } \\
\text { MaxEnt }\end{array}$ & $\begin{array}{l}\text { Echeverría et al. (2008), Newton } \\
\text { (2008a) }\end{array}$ \\
\hline Stand dynamics & FORMIND, PINQUE, Markov model & $\begin{array}{l}\text { Golicher and Newton (2007), Rüger } \\
\text { (2006), Rüger et al. (2007a,b), Zavala } \\
\text { et al. (2007) }\end{array}$ \\
\hline Forest restoration & $\begin{array}{l}\text { Statistical analysis, spatial MCA, } \\
\text { LANDIS II, FORMIND, PINQUE }\end{array}$ & $\begin{array}{l}\text { Gonzalez-Espinosa et al. (2007), } \\
\text { Golicher and Newton (2007), Rüger et } \\
\text { al. (2007a,b), Newton (2008a) }\end{array}$ \\
\hline Sustainable use & PVA, FORMIND, PINQUE & $\begin{array}{l}\text { Bekessy et al. (2004), Golicher and } \\
\text { Newton (2007), Rüger et al. (2007a, } \\
\text { 2008), Newton (2008b) }\end{array}$ \\
\hline $\begin{array}{l}\text { Decision-support tools, management } \\
\text { recommendations, policy options }\end{array}$ & $\begin{array}{l}\text { Scenarios, BBN, spatial MCA, outputs } \\
\text { from other modeling activities }\end{array}$ & $\begin{array}{l}\text { Miles et al. (2007), Newton (2008a, } \\
\text { 2009) }\end{array}$ \\
\hline
\end{tabular}

of edge effects was greater at edges with more pronounced contrasts. High and low contrast edges produced different responses in seed removal and seed dispersal across edges (López-Barrera et al. 2005, 2007b, Guzman-Guzman \& Williams-Linera 2006), seedling herbivory (López-Barrera et al. 2006), seed germination (López-Barrera and Newton 2005), diversity and abundance of small mammals, and edge microclimate (López-Barrera et al. 2007a). Edge type affected animal movement, with low-contrast edges enhancing small-mammal dispersal of seeds from the forest edge into adjacent old fields, whereas high-contrast edges tended to concentrate seed dispersal along edges (LópezBarrera et al. 2007a).

However, our finding that edge effects are widespread in tropical montane and temperate rain forests contradicts Harper et al. (2005), who hypothesized that edge effects are more likely to be pronounced in lowland tropical forests, where air temperatures and solar radiation are higher and 
Fig. 3. Loss of forest cover in three study areas, estimated from analysis of satellite remote-sensing imagery. Symbols: filled circle, Los Muermos-Ancud; filled triangle, Chiapas; empty square, Maule. Note that the percentage values given on the figure itself represent annual rates (\% per year) of forest loss.

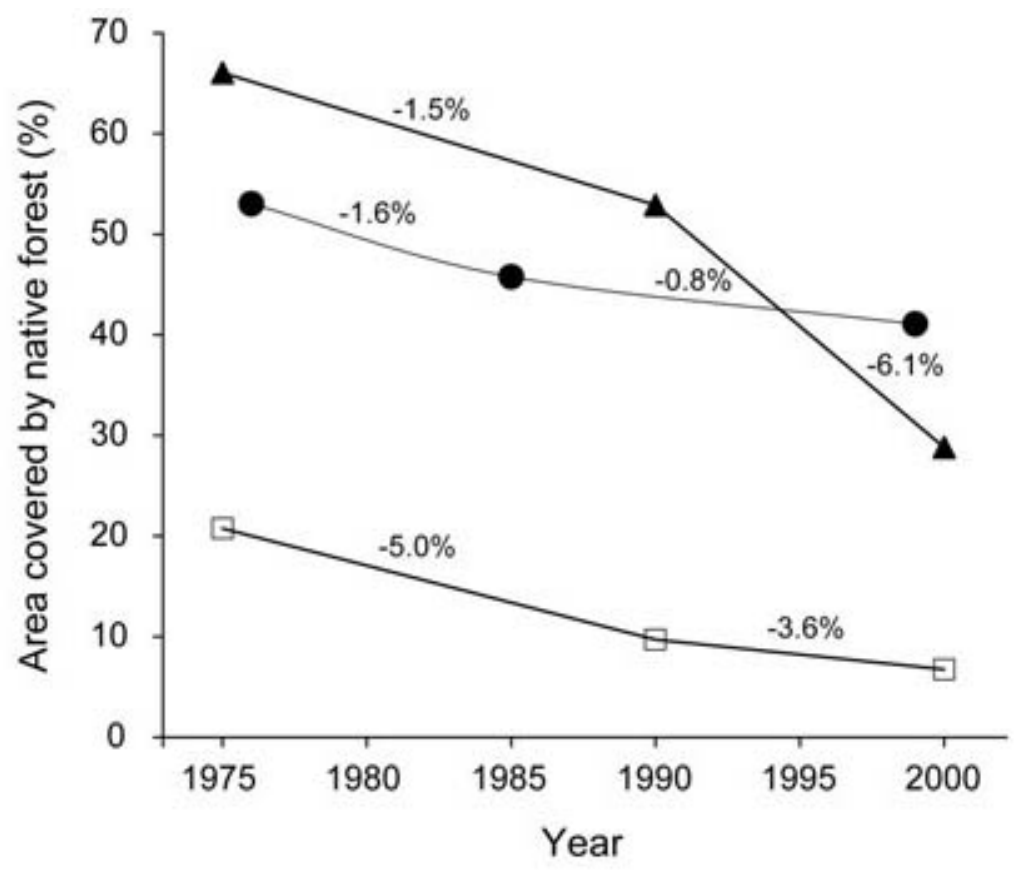

cloud cover lower. Furthermore, we demonstrated that a number of factors modulate the intensity, direction, and type of edge effect recorded. Such factors were recorded in $40 \%$ of our studies that recorded an edge effect, and included both the distribution and characteristics of species, edge orientation with respect to biotic or abiotic fluxes, and season or year of study. For example, changes in the distribution of seed predators and dispersers along the forest-edge gradient affected the processes of seed predation and dispersal (Díaz et al. 1999, López-Barrera 2003, López-Barrera et al. 2005, 2006, 2007a,b, Guzmán-Guzmán and WilliamsLinera 2006). These edge effects were determined by factors such as species, degree of canopy opening and the occurrence of mast-seeding years.

Another key finding was that edge effects were influenced by human disturbance within forest fragments, such as collection of firewood and livestock browsing. Most previous studies of edge effects compared well-preserved forest fragments with a highly disturbed surrounding matrix, ignoring the potential occurrence of human disturbance within forest fragments (Harper et al. 2005). Our results indicate that edge effects are more difficult to detect and are probably less ecologically important in forests subjected to such disturbance.

\section{STAND DYNAMICS AND DISTURBANCE IMPACTS}

Although the loss and fragmentation of forest area are generally considered to be the most important causes of biodiversity loss, further losses can occur because of human disturbance within remnant forest fragments. In the study areas considered here, the following forms of anthropogenic disturbance were chronic and widespread: logging of timber, fuelwood cutting, browsing by livestock, and development of infrastructure (principally roads) (Ramírez-Marcial et al. 2001, Aravena et al. 2002, Galindo-Jaimes et al. 2002, Williams-Linera 2002). 
Fig. 4. Forest fragmentation in three study areas, estimated from analysis of satellite remote-sensing imagery. Two measures of fragmentation are presented: (a) mean patch size, (b) patch density. Symbols: filled circle, Los Muermos; filled triangle, Chiapas; empty square, Maule. Values were also obtained for Central Veracruz (not illustrated) for two dates, where mean patch size declined from 1176 ha in 1984 to 1291 ha in 2000 , and patch density declined from 0.013 to 0.009 over the same period.
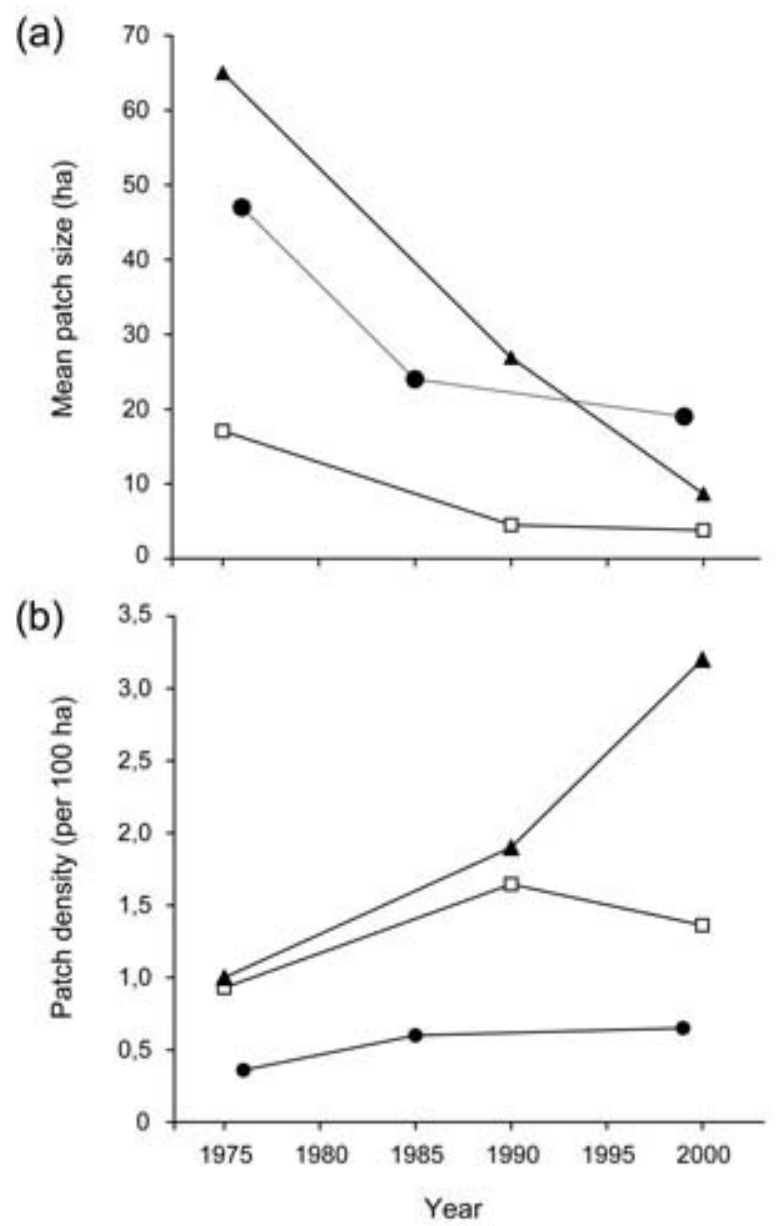

Human-set fires were also a common feature, except in Veracruz.

Substantial impacts of human disturbance on forest stand structure and composition were identified by analysis of gradients of disturbance in four study areas, using regression analyses (Newton et al. 2007), and by analysis of field data derived from successional chronosequences in Oaxaca, Mexico (del Castillo and Blanco-Macías 2007). These results were supported by modeling exercises exploring dynamics of montane forests in Chiapas, where the long-term dynamics of forest stands were explored using Markovian stochastic models (Zavala et al. 2007). Transition matrices were used to evaluate the probability of replacement of canopy-tree species by other species, based on their ecological characteristics and regeneration patterns, which were determined using results from field surveys. Results indicated the potential for competitive exclusion of pines (Pinus spp.) and oaks (Quercus spp.) by shade-tolerant broadleaved tree species in the absence of human disturbance, but also highlighted the influence of environmental 
Table 2. Summary of results obtained by investigations assessing edge effects in tropical montane and south temperate rainforests, two forest types that have been almost entirely neglected by previous research (Harper et al. 2005, Ries et al. 2004). Results presented of measurements of ecological processes, patterns, and microclimate at the forest edge (zero meters) compared with the forest interior, showing higher or lower values of the response variable at the edge, or no difference. Modulators are factors that conditioned the observed response. "Hard" and "soft" edges refer to high- and low-contrast edges, respectively (see text). (Adapted from López-Barrera et al. 2007a).

\begin{tabular}{|c|c|c|c|c|c|}
\hline Response variable & Region & Modulators & Higher & Lower & No difference \\
\hline \multicolumn{6}{|l|}{ Dynamic processes } \\
\hline \multirow[t]{2}{*}{ Seed rain } & Chiloé & Only fleshy-fruited species & $\mathrm{X}$ & & \\
\hline & Chiloé & Landscape type & & $\mathrm{X}$ & \\
\hline \multirow[t]{2}{*}{ Avian nest predation } & Chiloé & & $\mathrm{X}$ & & \\
\hline & Chiloé & & & $\mathrm{X}$ & \\
\hline Seed germination & Chiapas & Species identity & $\mathrm{X}$ & & \\
\hline \multirow{3}{*}{$\begin{array}{l}\text { Seed removal and/or } \\
\text { predation }\end{array}$} & Chiapas & Only non-masting years & $\mathrm{X}$ & & \\
\hline & Veracruz & & & $\mathrm{X}$ & \\
\hline & Chiloé & $\begin{array}{l}\text { Species identity, season, and } \\
\text { canopy opening }\end{array}$ & & $\mathrm{X}$ & \\
\hline \multirow[t]{3}{*}{ Seedling herbivory } & Chiloé & & & $\mathrm{X}$ & \\
\hline & Chiapas & $\begin{array}{l}\text { Edge specific: only in hard } \\
\text { edges }\end{array}$ & $\mathrm{X}$ & & \\
\hline & Veracruz & $\begin{array}{l}\text { Season specific: only in the } \\
\text { soft edge during the dry season }\end{array}$ & $\mathrm{X}$ & & \\
\hline \multirow{3}{*}{$\begin{array}{l}\text { Seedling performance } \\
\text { (survival and growth) }\end{array}$} & Chiloé & & $\mathrm{X}$ & & \\
\hline & Chiloé & & $\mathrm{X}$ & & \\
\hline & Veracruz & & $\mathrm{X}$ & & \\
\hline Tree growth rate & & Species dependent & $\mathrm{X}$ & & \\
\hline \multicolumn{6}{|l|}{ Ecological flows } \\
\hline $\begin{array}{l}\text { Fog interception and tree } \\
\text { regeneration }\end{array}$ & Fray Jorge & Fog influx direction & $\mathrm{X}$ & & \\
\hline $\begin{array}{l}\text { Seed movement from edge } \\
\text { into the exterior }\end{array}$ & Chiapas & $\begin{array}{l}\text { Edge specific: only in soft } \\
\text { edges }\end{array}$ & $\mathrm{X}$ & & \\
\hline
\end{tabular}




\begin{tabular}{|c|c|c|c|c|c|}
\hline \multirow{2}{*}{$\begin{array}{l}\text { Woody species richness/ } \\
\text { diversity }\end{array}$} & \multicolumn{4}{|l|}{ Chiapas } & $\mathrm{X}$ \\
\hline & \multicolumn{4}{|l|}{ Veracruz } & $\mathrm{X}$ \\
\hline $\begin{array}{l}\text { Epiphyte cover and species } \\
\text { richness }\end{array}$ & \multicolumn{3}{|l|}{ Chiloé } & $\mathrm{X}$ & \\
\hline Bryophyte species richness & \multicolumn{3}{|l|}{ Chiloé } & $\mathrm{X}$ & \\
\hline Avian species richness & \multicolumn{3}{|l|}{ Chiloé } & & $\mathrm{X}$ \\
\hline \multirow[t]{2}{*}{$\begin{array}{l}\text { Diversity and abundance of } \\
\text { native small mammals }\end{array}$} & Chiapas & $\begin{array}{l}\text { Edge specific: only in soft } \\
\text { edges }\end{array}$ & \multicolumn{3}{|l|}{$X$} \\
\hline & Veracruz & $\begin{array}{l}\text { Only in fragments with soft } \\
\text { edges }\end{array}$ & \multicolumn{3}{|l|}{$X$} \\
\hline Overall tree seedling & Chiloé & $\begin{array}{l}\text { Species identity and shade } \\
\text { tolerance }\end{array}$ & $\mathrm{X}$ & & \\
\hline \multirow[t]{2}{*}{ and sapling density } & \multicolumn{4}{|l|}{ Chiapas } & $\mathrm{X}$ \\
\hline & \multicolumn{3}{|l|}{ Veracruz } & $\mathrm{X}$ & \\
\hline \multicolumn{6}{|l|}{ Microclimate } \\
\hline \multirow[t]{3}{*}{ Soil moisture } & $\begin{array}{l}\text { Semiarid } \\
\text { Chile }\end{array}$ & Fog influx direction & $\mathrm{X}$ & & \\
\hline & \multicolumn{3}{|l|}{ Veracruz } & $\mathrm{X}$ & \\
\hline & \multicolumn{3}{|l|}{ Chiapas } & & $\mathrm{X}$ \\
\hline Light & Chiapas & $\begin{array}{l}\text { Edge specific: only in hard } \\
\text { edges. }\end{array}$ & $\mathrm{X}$ & & \\
\hline Air temperature & Veracruz & & $X$ & & \\
\hline
\end{tabular}

variables (such as rainfall availability) on successional trajectories.

In addition, also in Chiapas, an individual tree-based gap model was parameterized using field data, and used to examine the process of forest recovery following disturbance (Golicher and Newton 2007). Results indicated that the recovery rate of tropical montane forest following human disturbance is very low, even when a source of colonists is assumed to exist nearby. Simulations suggested that it may take several hundred years to re-establish a canopy dominated by shade-tolerant tree species (Fig. 5). In forests subjected to recurrent disturbance, such tree species may become locally extinct. These results were further supported by simulations performed with the process-based forest growth model FORMIND (Köhler and Huth 1998, Köhler et al. 2001) for tropical montane forest in Veracruz, where relatively slow-growing, shade-tolerant canopy tree species did not achieve steady-state basal area until around ca. 300 years after disturbance (Rüger et al. 2008). Modeling results from temperate rain forest in Chile also indicated slow recovery following human disturbance (Rüger et al. 2007b). When long-term dynamics of a forest in Chiloé (Chile) following a clearfell was simulated over a 1500-year period, including natural mediumscale disturbances (e.g., windthrows), total basal area reached a steady state after 200 years (Fig. 6). However, the basal area of some species attained a steady state only after 1000 years. 
Statistical analyses of field data together with remote-sensing imagery also identified interactions between forest fragmentation and anthropogenic disturbance within forest patches. For example, in southern Chile, significant negative relationships were found between patch size and indicators of human disturbance such as the number of animal trails, counts of feces produced by livestock, and the number of cut tree stumps (Echeverría et al. 2007b).

\section{SPECIES RICHNESS}

The impact of forest fragmentation on tree species richness was explored using regression models, by relating the results of floristic surveys to different measures of forest fragmentation derived from analysis of remote-sensing imagery. For example, in southern Chile, data from 63 sampling plots distributed in 51 forest fragments with different spatial attributes were sampled. Results indicated that the area, core area, edge length, and proximity of forest fragments were all negatively associated with mean species richness of pioneer species, and positively associated with richness of forest interior species. Patch size was the most important attribute influencing different measures of species composition, being significantly related to the abundance of tree and shrub species associated with interior and edge habitats (Echeverría et al. 2007b).

In Chiapas, we identified all tree species within 204 field plots (each $1000 \mathrm{~m}^{2}$ ) and measured different environmental, human disturbance-related, and spatial variables using remote sensing and GIS data (Cayuela et al. 2006d). To obtain a predictive model of $\alpha$ tree diversity (Fisher's alpha) based on selected explanatory variables, we used a generalized linear model with a gamma error distribution. Mantel tests of matrix correspondence were used to determine whether similarities in floristic composition were correlated with similarities in the explanatory variables. The model for $\alpha$ diversity explained $44 \%$ of the overall variability, of which most was related to precipitation, temperature, normalized difference vegetation index (NDVI), and canopy cover. These results were used to identify and assign conservation priority to unexplored areas with potentially high tree diversity (Cayuela et al. 2006d).

\section{GENETIC DIVERSITY}

Genetic variation is rarely considered in analyses of SFM, despite being widely acknowledged as a key component of biodiversity. To assess the potential impacts of forest loss on genetic diversity, patterns of genetic variation within selected tree species were analyzed using molecular markers. Results revealed an unexpectedly high degree of population differentiation in many species (Table 3). In the 10 species investigated by random amplification of polymorphic DNA (RAPD), the mean percentage of genetic variation recorded between populations was $19.4 \%$, reaching a maximum of $54.8 \%$ in the endemic vine Berberidopsis corallina. Hamrick et al. (1992), in a review of isozyme analyses of 195 woody perennial plants, reported an overall mean value of $8.4 \%$ differentiation among populations, less than half the value recorded here with DNA markers. Perhaps significantly, most species surveyed by Hamrick et al. (1992) were northtemperate or lowland-tropical in origin. Evidence suggests that tropical montane and south temperate rainforest trees display very different biogeographic and evolutionary histories, characterized by relatively limited post-glacial migration and longterm isolation between populations (Newton et al. 2002, Premoli et al. 2002, 2007). High population differentiation implies that relatively high losses of genetic variation are likely to have occurred as a result of deforestation, although the lack of baseline data makes these losses difficult to estimate with precision.

Forest fragmentation can also affect genetic variation within species, by influencing processes of gene flow, inbreeding, and genetic drift (Fig. 1). Several of the species examined, notably Pinus chiapensis, Berberidopsis corallina, and Pilgerodendron uviferum displayed relatively low intraspecific genetic variation (Table 3), suggesting that fragmentation, and consequent isolation of populations, may be reducing genetic variation within these species. Analyses of mating system in several populations of the threatened conifer Pinus chiapensis revealed inbreeding depression in relatively small, isolated populations, resulting in low seed germination (Premoli et al. 2007). The most detailed analysis of fragmentation effects on genetic variation was undertaken with the birdpollinated tree Embothrium coccineum. Seedling growth correlated positively with the number of alleles, indicating a deleterious effect of inbreeding. However, as a result of the foraging behaviour of 
Fig. 5. Dynamics of forest structure and composition following human disturbance. The graphs present results from simulations produced by an individual tree-based gap model parameterized for montane forests in Chiapas (Golicher 2001). Three disturbance regimes were simulated, following clearcutting of a patch of forest (to simulate traditional land-use practices): (a) no subsequent disturbance, (b) recurrent disturbance caused by slash-and-burn agriculture, and (c) recurrent disturbance caused by timber and fuelwood harvesting. Numbers refer to different tree species; 1: Pinus oocarpa 2: Pinus maximinoi 3: Quercus segoviensis 4: Quercus crispipilis 5: Heliophilic shrubs 6: Understorey 7: Generic broadleaf 8: Total. Note the slow recovery of late-successional, broadleaved species (7).
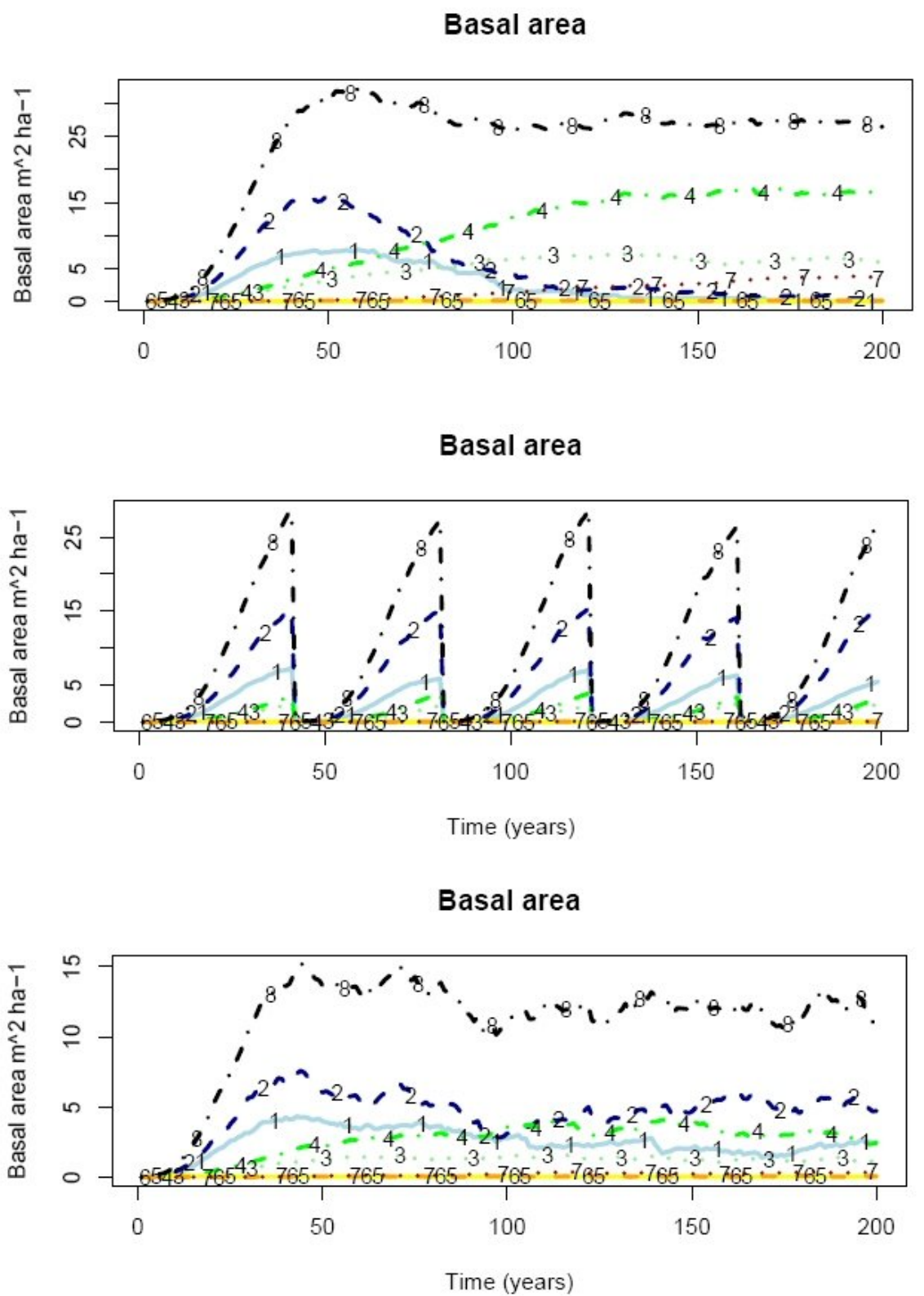
Fig. 6. Simulation of regeneration of Valdivian temperate rain forest in northern Chiloé Island, Chile, after large-scale disturbance. Mean and standard deviation of basal area of the different tree species for 10 simulations for 1 ha and 1500 years (individuals $\geq 5 \mathrm{~cm} \mathrm{dbh}$ ). Note that the first 400 years of succession were dominated by Eucryphia cordifolia, which was then replaced by more shade-tolerant species such as Laureliopsis philippiana and Aextoxicon punctatum.

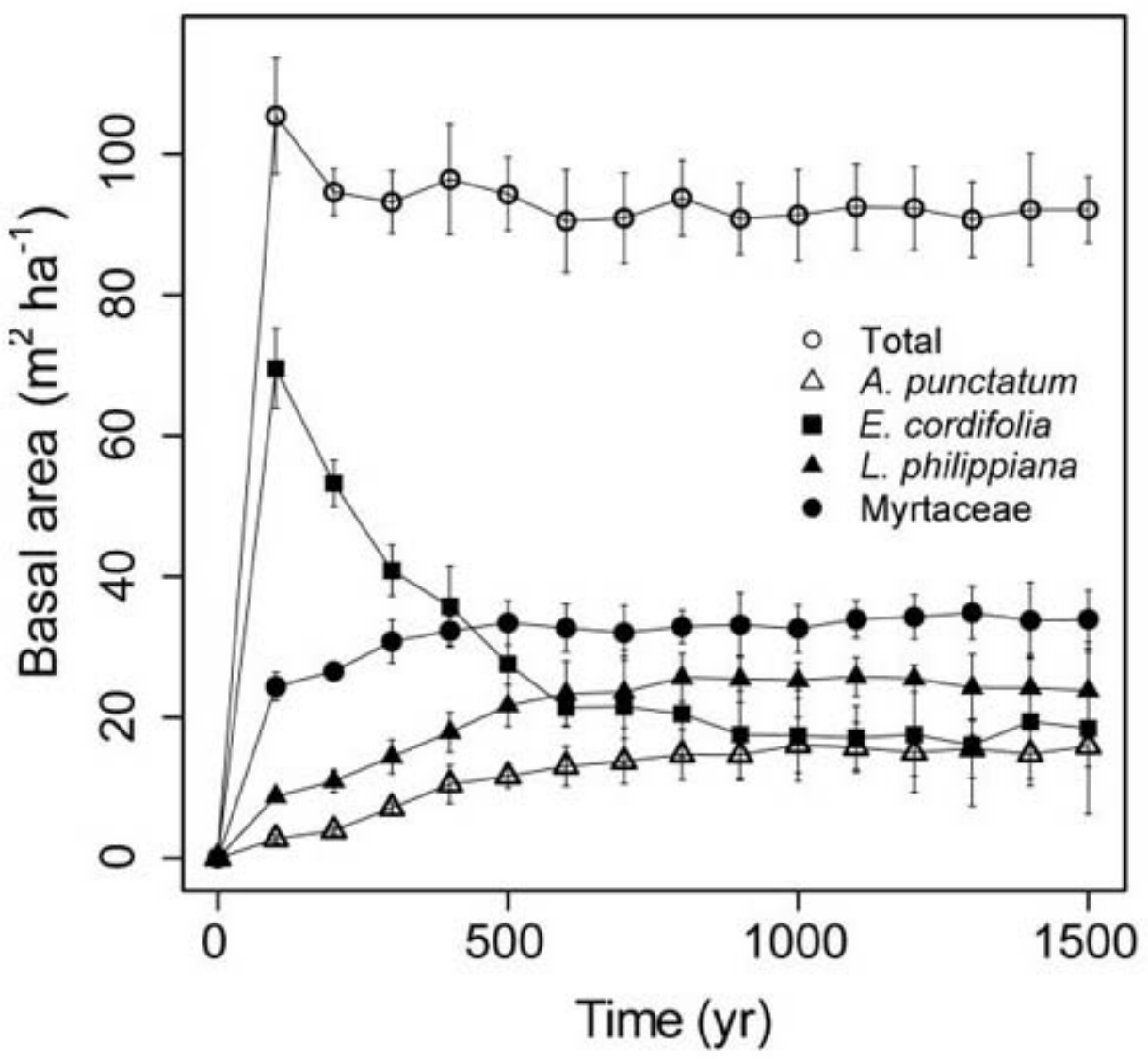

bird pollinators, higher outcrossing rates were recorded in smaller forest fragments than in larger patches, reducing the risk of inbreeding in the former (Mathiasen et al. 2007). These results indicate that fragmentation can have positive effects on gene flow in some species, by influencing animal behavior and plant-animal interactions.

\section{SUSTAINABLE USE}

The potential for sustainable harvesting of timber and fuelwood was assessed using the process-based forest-growth model FORMIND in central
Veracruz and in Chiloé. Simulation results show that both forest types have potential for sustained wood production (Rüger et al. 2007b, 2008). Estimated potential harvests of up to $12 \mathrm{~m}^{3} \mathrm{ha}^{-1} \mathrm{yr}^{-1}$ for Mexican montane cloud forest and up to $13 \mathrm{~m}^{3}$ $\mathrm{ha}^{-1} \mathrm{yr}^{-1}$ for Chilean temperate rain forest are substantially lower than growth rates of plantations of Eucalyptus spp. or Pinus radiata, which reach mean annual volume increments of 40 and $30 \mathrm{~m}^{3}$ $\mathrm{ha}^{-1}$, respectively (Ugalde and Pérez 2001). However, simulated annual volume increments are relatively high compared with those predicted for various tropical lowland forests, which range between 1 and $4 \mathrm{~m}^{3} \mathrm{ha}^{-1}$ (Huth and Ditzer 2001, 
Table 3. Comparison of results obtained using DNA markers to assess patterns of genetic variation in woody species native to Mexico (M) and southern South America (SA). P\% indicates percentage of polymorphic loci, a measure of the extent of genetic variation within species. (All results obtained with RAPD markers, apart from *, obtained with inter-SSR markers; values in parentheses obtained with isozyme markers). All species are trees apart from Berberidopsis, which is a woody vine. (Adapted from Premoli et al. 2007.)

\begin{tabular}{lcccc}
\hline \hline Species & $\begin{array}{c}\text { Region where } \\
\text { native }\end{array}$ & Sample size & $\mathrm{P}(\%)$ & $\begin{array}{c}\text { \% of variation recorded } \\
\text { between populations }\end{array}$ \\
\hline Aextoxicon punctatum & SA & 283 & 63.7 & 12.1 \\
Araucaria araucana & SA & 192 & 68.4 & 12.8 \\
Berberidopsis corallina & SA & 44 & 15.1 & 54.8 \\
Fagus grandifolia var. mexicana & M & 96 & 39.1 & 15.6 \\
Fitzroya cupressoides & SA & 89 & 72.4 & 14.4 \\
Legrandia concinna & SA & $(720)$ & $(61.9)$ & $(8.3)$ \\
Luma apiculata & SA & $(385)$ & $(67)$ & $(41)$ \\
Magnolia schiedeana* & M & 64 & 50.0 & $(12.4)$ \\
Magnolia sharpii $*$ & M & 80 & 56.0 & 25.7 \\
Pilgerodendron uviferum & SA & 192 & 35.7 & 10.6 \\
Pinus chiapensis & & $(600)$ & $(86)$ & 18.6 \\
Podocarpus nubigena & M & 138 & 24.5 & 22.6 \\
Podocarpus salignus & SA & $(260)$ & $(90.9)$ & $(21.6)$ \\
\hline
\end{tabular}

Kammesheidt et al. 2002, van Gardingen et al. 2003). However, harvesting the forests at such high rates has a strong impact on the size structure and species composition of the forests. For both forest types, an ecological index measuring the similarity of the simulated logged forest to undisturbed oldgrowth forest consistently decreased linearly with increasing levels of wood extraction (Fig. 7). Moreover, FORMIND simulations indicated that even at low logging intensities, the number of large trees markedly decreases over the long term. As a consequence, forest structure becomes simplified and habitat value is reduced (Rüger et al. 2007b).

Similarly, exploration of the individual tree-based gap model (PINQUE) in Chiapas suggested that the potential exists for sustainable timber harvesting (Golicher and Newton 2007). However, the harvesting regime adopted has a major impact on both forest structure and composition. Following harvesting or forest clearance, pines will initially tend to dominate the forest canopy, but in the absence of any further disturbance, oaks will tend to dominate after a period of approximately 70 years (Fig. 5). However, if subjected to recurrent disturbance equivalent to timber cutting, pine dominance within the stands (as indicated by basal area values) may continue indefinitely. A regime of less intensive use, involving disturbance of small patches, creates a forest that is heterogeneous in structure in which either pines or oaks may dominate. 
Fig. 7. Ecological Index (EI) vs. mean annual harvest for four selective-logging strategies of tropical montane cloud forest in central Veracruz, Mexico, which target only specific plant functional types (PFTs) and diameter ranges and three logging strategies (selective logging with and without large-tree retention, clearcutting in narrow bands) of Valdivian temperate rainforest in northern Chiloé Island, Chile. EI provides a combined measure of structural change, compositional change, stand leaf area index, and the number of old trees ( $>1 \mathrm{~m} \mathrm{dbh}$ ) (for full details, see Rüger et al. 2007b). Undisturbed oldgrowth forest has an EI value close to 1.

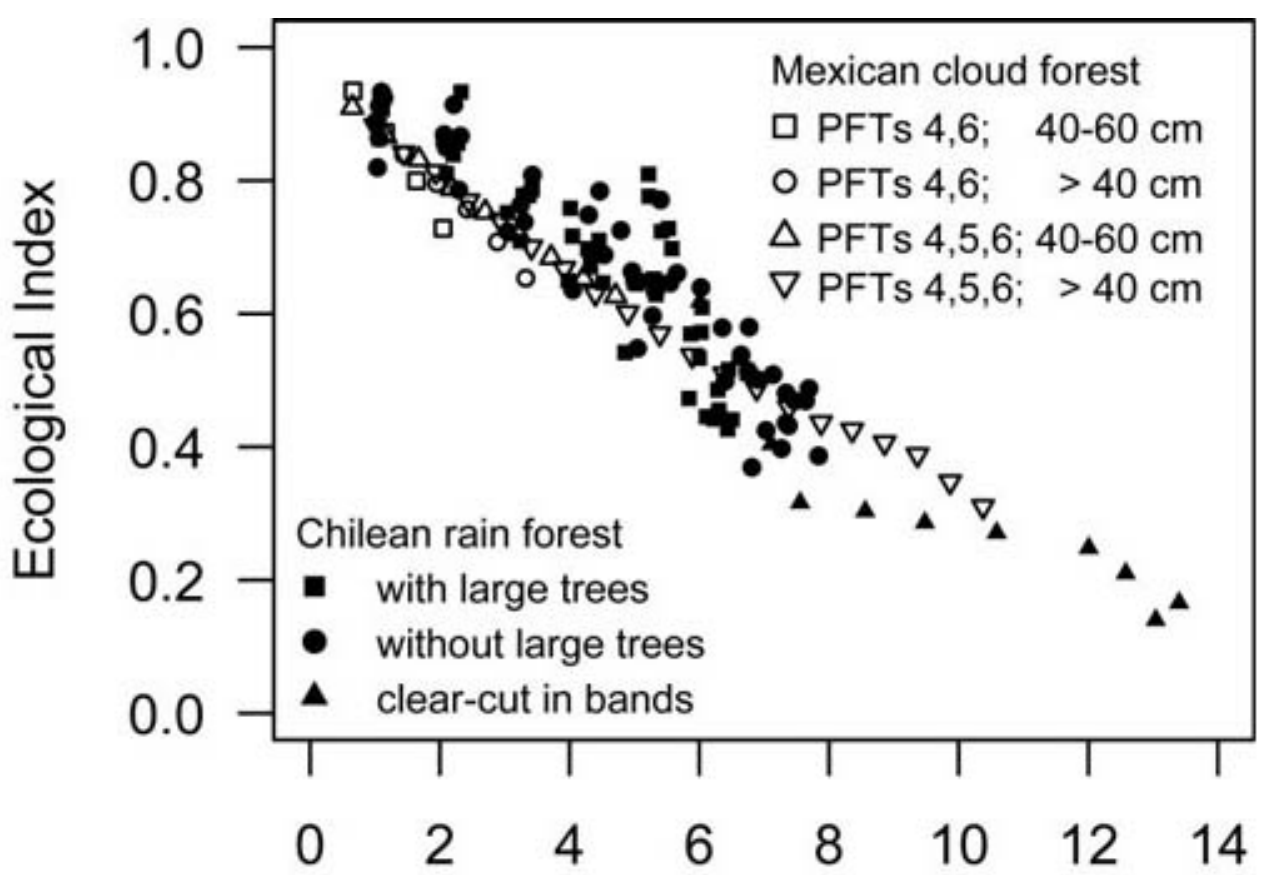

Mean annual harvest $\left(\mathrm{m}^{3} \mathrm{ha}^{-1}\right)$

In addition, population viability analyses (PVA) based on the use of transition matrix models were used to examine the potential impact of harvesting on the populations of selected tree species. For example, Bekessy et al. (2004) used a spatially structured metapopulation model based on transition matrices to examine harvesting impacts on the threatened conifer Araucaria araucana, together with other disturbances including fire, timber harvesting, and volcanic activity. Results indicated that the species has very limited ability to recover after disturbance, although seed harvesting appeared to be having relatively little effect on population viability compared with the other forms of disturbance assessed.

\section{RESTORATION}

We established experimental restoration trials on 33 sites within six study areas (Gonzalez-Espinosa et al. 2007). Most experiments focused on establishment of native tree species on former agricultural land, or floristic enrichment of impoverished secondary stands (Alvarez-Aquino et al. 2004), and were analyzed using standard statistical approaches (such as ANOVA). Results indicate that establishment of native tree species can be achieved through a variety of means, including artificial establishment and/or encouragement of natural regeneration, in a wide range of site conditions. A range of factors were found to influence the growth and survival of established 
trees, including light availability, soil conditions, and drainage. Most importantly, establishment of shade-tolerant tree species was often enhanced by the presence of other plants, emphasizing the importance of facilitation as an establishment mechanism and highlighting the importance of understanding successional processes when developing forest restoration practices.

Experimental investigations were complemented by forest modeling simulations, using PINQUE and FORMIND. Results indicated that these forests take a great deal of time to recover following disturbance. Whereas structural characteristics such as total stem number, basal area, or leaf area index recover rapidly, variables characterizing old-growth conditions such as late-successional species composition or the number of large trees require a timescale of centuries to re-establish (Golicher and Newton 2007, Rüger et al. 2007a,b, 2008).

\section{DATA INTEGRATION FOR DECISION SUPPORT}

The analytical framework underpinning this research initiative (Fig. 2) was designed to support the integration of research results to provide support to decision makers, with the overall goal of assisting progress toward SFM. Many of the individual research activities produced outputs of value to this process. In particular, the production of map-based research outputs using GIS greatly facilitated data integration and presentation in a form that could readily be understood by decision makers. Statistical models of the spatial dynamics of forest cover were integrated with species distribution data, and were used to identify areas of actual or potential biodiversity loss, and thereby to identify priorities for conservation action (Wilson et al. 2005, 2007, Cayuela et al. 2006a,b,c,d, Echeverría et al. 2007a, 2008, Rey Benayas et al. 2007). Similarly, information on genetic variation was used to identify management priorities (Premoli et al. 2007), and recommendations for sustainable harvesting were developed based on models of stand dynamics (Rüger et al. 2007a) and tree population dynamics (Bekessy et al. 2004). Research results were also used to develop and test indicators, which could be used to monitor progress toward SFM (Newton et al. 2007).

Two other analytical approaches were employed with the specific aim of integrating research results and communicating findings to decision makers (Appendix 2). Firstly, Bayesian belief networks $(\mathrm{BBN})$ were used to analyze and explore expert knowledge regarding the threats to forest biodiversity within the study areas and to develop projections regarding likely future trends (Miles et al. 2007). This method is particularly applicable to this kind of domain, characterized by high uncertainty and dependence on expert knowledge (Newton 2009). Model output, presented in the form of probabilities associated with different outcomes, can readily be used to provide a type of risk assessment, in this case relating to the likelihood of future biodiversity loss as a result of unsustainable land-use practices.

Secondly, scenarios were developed exploring potential future trends in forest biodiversity, in relation to different management interventions and policy developments (Miles et al. 2007). Scenario planning is increasingly being recognized as a useful tool for developing conservation management approaches under such uncertain conditions (Newton 2007a). A scenario can be defined in this context as an account of a plausible future. In this case, scenarios were informed by results obtained from the different research activities, including model outputs. In this way, scenario building offers a tool for integration of data, models, and other evidence (such as experimental results) in a way that links closely to the needs of decision makers by providing a tool for exploring the potential impacts of different management and policy interventions. The approach was also used to identify priorities for management action (Miles et al. 2007).

\section{CONCLUSIONS}

Sturtevant et al. (2007) suggest that although developed primarily for North American boreal forests, the SFM toolkit approach should be applicable to other socioeconomic and ecological contexts. Our results support this contention, as a variety of modeling approaches developed for north-temperate forests have successfully been applied to a range of forest areas in Latin America. However, the situation in these areas is very different from that prevailing in many northtemperate countries. Our research results indicated that high rates of forest loss have occurred in each of the study areas during recent decades. The annual rates of deforestation recorded generally fall within the range of values typical for areas undergoing 
rapid change in forest cover: $2 \%$ to $5 \%$ (Lambin et al. 2003). However, the rate of forest loss recorded in Chiapas during the period $1990-2000\left(6.1 \% \mathrm{yr}^{-1}\right)$ is exceptionally high, exceeding that $\left(6 \% \mathrm{yr}^{-1}\right)$ recorded for lowland deciduous forest in eastern Santa Cruz, Bolivia in the mid 1990s (Steininger et al. 2001), thought to be one of the highest deforestation rates reported anywhere in the world. In general, forest loss was associated with conversion to either crop or pasture lands by smallholders, or as in the case of Chile, conversion to plantation forestry, processes neglected by previous reviews (Lambin et al. 2001, 2003). Forest loss has been accompanied by substantial fragmentation. For example, over the last three decades, total core area of forest patches declined by $96 \%$ and $90 \%$ in Maule and Chiapas, respectively, whereas mean proximity of forest fragments declined by $98.7 \%$ and $98.6 \%$, respectively (Rey Benayas et al. 2007).

Within the forest fragments that remain, human disturbance was found to be chronic and widespread. Forest patches are being subjected to tree cutting, browsing by livestock, construction of roads and tracks, and human-set fire, often in combination. Such disturbance has a negative impact on tree species richness (Ramírez-Marcial et al. 2001, Aravena et al. 2002, Galindo-Jaimes et al. 2002, Cayuela et al. 2006b,d, Echeverría et al. 2007a,b, Rey Benayas et al. 2007). In Chiapas and Oaxaca, the forests have been subjected to human disturbance over a prolonged period, as traditional land use involved shifting agriculture followed by land abandonment, providing opportunities for the forest to recover. However, this traditional form of land use is now being abandoned, and increasingly agriculture is being intensified in fixed locations through the use of fertilizers, limiting opportunities for forest recovery. Our results also provide clear evidence of interactions between fragmentation and other anthropogenic impacts. For example, in Muermos, southern Chile, intensity of browsing by livestock and harvesting of trees for timber were found to be higher in smaller forest fragments (Echeverría et al. 2007b). As forest fragments decline in area, they become more accessible to both people and livestock, resulting in a positive feedback between forest loss, fragmentation, and degradation. As a result, remnant forest patches become increasingly dominated by early successional species, and old-growth forest areas are progressively eliminated from the landscape (Cayuela et al. 2006b,d, Echeverría et al. 2007a,b).
Approaches to SFM in areas experiencing rapid forest loss will necessarily differ from those typically being adopted in north-temperate countries, where forest areas are relatively stable and management efforts are often supported by a strong legislative framework, institutional capacity, and substantial financial resources. The areas of Latin America that we investigated lack such an enabling environment for SFM. The main priorities are to prevent further forest loss and degradation and to address the degradation that has already occurred, for example, through management interventions aimed at forest restoration. Any modeling toolkit would, therefore, need to include tools for analyzing the process of forest loss and degradation, such as the statistical and rule-based approaches included here, as well as response options such as restoration and sustainable harvesting (Appendix 3).

The development of tools to support SFM in regions such as Latin America faces a number of significant challenges. The parameterization of dynamic forest models is hindered by the lack of information about the ecological characteristics of most of the tree species, an issue compounded by the high species richness and endemicity of the forests concerned. Unlike in North America, it is not the case that a large number of well-parameterized models are already available. There is an urgent need for collection of new field data for model parameterization, as existing forest inventory data are few. Further information is also required on the ecological impacts of different human activities. Our research has indicated that forests may be subjected to a variety of different activities simultaneously, which may have interactive effects on ecological processes. Exploration of such interactions remains a significant modeling challenge.

The issue of scale is recognized to be a central challenge in ecology (Levin 1992, Wiens 1989), and an ability to integrate information obtained at a range of different scales represents an important attribute of any modeling toolkit for SFM. As suggested by Sturtevant et al. (2007), metamodeling offers a potential approach to assist in this process, for example by using the output of standbased models (such as FORMIND and PINQUE considered here) to parameterize coarser-scaled models (such as LANDIS II). However, scaling up some ecological phenomena (such as edge effects and processes influencing genetic variation) is particularly challenging (Appendix 2). Land- 
management decisions should ideally be made at the landscape scale, but the scope for this within the study areas examined here is currently limited because of the lack of appropriate spatial planning processes relating to native forests. Forest loss and degradation, although creating patterns observable at the landscape scale, are largely being produced as a result of the actions of individual landowners at very local scales. Tools may, therefore, be required for scaling up the impacts of land-use decisions made by smallholders, such as agentbased modeling approaches (Berger and Schreinemachers 2006, Huigen 2004, Janssen and Ostrom 2006).

Another key challenge is the integration of different modeling activities in a way that supports decision making. According to Sturtevant et al. (2007), the toolkit approach involves the development of metamodels, created by linking existing models together through some form of loose coupling. In the research described here a degree of such linkage was achieved, for example, through the integration of statistical models of forest loss, fragmentation and species richness to provide forecasts of potential biodiversity loss under different management regimes. The potential exists for much greater integration between models (Appendix 3). For example, current research is focusing on linking statistical models of land-cover change with LANDIS-II and spatial MCA approaches (Newton 2008a). The current aim is for all modeling tools to share the same spatial data sets, which facilitates data transfer and enables strong links to be made with GIS and its associated analytical functionality. However, for some domains (such as genetic variation) this may be difficult to achieve, and some modeling tools will necessarily remain conceptual or qualitative in nature. There is also a need to integrate other forms of evidence besides models, including results from experimental investigations and field surveys, such as the restoration trials and analyses of edge effects described here. Our experience to date suggests that BBNs (Appendix 2) may be particularly valuable for integrating the output of different models, together with other forms of evidence, such as experimental results and expert knowledge, to provide decision-support tools (Newton 2008a, Miles et al. 2007). Scenario planning and spatial MCA approaches (Appendix 2) also have demonstrable value in supporting dialog with decision makers and exploring the potential impacts of different management decisions in domains characterized by high uncertainty (Miles et al. 2007), and are being applied in current research.
Sturtevant et al. (2007) also envisage the toolkit approach being implemented as a collaborative process involving the participation of a range of stakeholders. This is more difficult in areas without an established institutional or policy framework for forest management planning, and in areas where the technical capacity for SFM is very limited, as in the study areas examined here. Stakeholder dialog has, therefore, been limited to date. However, this is being addressed in the latest phase of the research, where a process of consultation with stakeholders has been initiated, involving representatives from local communities and private landowners as well as government and non-government organizations (Newton 2008a). Stakeholder involvement will inevitably require an increased emphasis on the role of forests in supporting livelihoods, as well as on forest biodiversity. An example of how this may be modeled is provided by the CEPFOR project, which examined the socioeconomic values of forests in Mexico and Bolivia, using a variety of participatory approaches (Marshall et al. 2006, Newton et al. 2006). A key current challenge is to develop methods for mapping the value of different ecosystem services on which livelihoods depend (Naidoo and Ricketts 2006) so that this information may be incorporated in spatial planning. Such analyses could potentially be integrated with spatially explicit models of forest dynamics, providing a tool for exploring provision of ecosystem services under different scenarios of environmental change, an approach we are now beginning to explore (Newton 2008a).

Responses to this article can be read online at:

http://www.ecologyandsociety.org/voll4/iss2/art2/responses/

\section{Acknowledgments:}

Most of the research described here was undertaken in three projects supported by the European Commission (INCO programme), namely SUCRE (ERBIC18CT970146), BIOCORES (ICA4-

CT-2001-10095), and ReForLan (INCO-DEV-3 N 032132), and three Darwin Initiative (DEFRA, UK Government) grants to the senior author. Additional funding was provided by a variety of sources within the partner countries. All sources of financial support are gratefully acknowledged. 


\section{LITERATURE CITED}

Alvarez-Aquino, C., G. Williams-Linera, and A. C. Newton. 2004. Experimental native tree seedling establishment for the restoration of a Mexican cloud forest. Restoration Ecology 12(3):412-418.

Aravena, J. C., M. R. Carmona, C. A. Perez, and J. J. Armesto. 2002. Changes in tree species richness, stand structure and soil properties in a successional chronosequence in northern Chiloe Island, Chile. Revista Chilena de Historia Natural 75(2):339-360.

Arroyo, M. K., C. Lohengrin, A. Peñaloza, M. Riveros, and A. M. Faggi. 1995. Relaciones fitogeográficas y patrones regionales de riqueza de especies en la flora del bosque lluvioso templado de Sudamérica. Pages 71-92 in J. J. Armesto, C. Villagrán, and M. K. Arroyo, editors. Ecología de los bosques nativos de Chile. Textos Universitarios/ Monografias, Santiago, Chile.

Bekessy, S. A., A. C. Newton, J. C. Fox, A. Lara, A. Premoli, M. Cortes, M. Gonzalez, B. Burns, L. Gallo, F. Isquierdo, and M. A. Burgman. 2004. Monkey puzzle tree in southern Chile: effects of timber and seed harvest. Pages 48-63 in H. R. Açkakaya, M. A. Burgman, O. Kindval, C. C. Wood, P. Sjögren-Gulve, J. Hatfield, and M. McCarthy, editors. Species conservation and management: case studies. Oxford University Press, Oxford, UK.

Berger, T., and P. Schreinemachers. 2006. Creating agents and landscapes for multiagent systems from random samples. Ecology and Society 11(2): 19. [online] URL: http://www.ecologyandso ciety.org/vol11/iss2/art19/.

Cayuela L., D. J. Golicher, and J. M. ReyBenayas. 2006a. The extent, distribution and fragmentation of vanishing montane cloud forest in the Highlands of Chiapas, Mexico. Biotropica 38 (4):544-554.

Cayuela, L., D. J. Golicher, J. M. Rey-Benayas, M. González-Espinosa, and N. Ramírez-Marcial. 2006b. Fragmentation, disturbance and tree diversity conservation in tropical montane forests. Journal of Applied Ecology 43:1172-1182.

Cayuela, L, J. M. Rey Benayas, and C. Echeverría. 2006c. Clearance and fragmentation of tropical montane forests in the Highlands of Chiapas, Mexico (1975-2000). Forest Ecology and Management 226:208-218.

Cayuela, L., J. M. Rey Benayas, A. Justel, and J. Salas-Rey. 2006d. Modelling tree diversity in a highly fragmented tropical montane landscape. Global Ecology and Biogeography 15:602-613.

Del Castillo, R. F., and A. Blanco-Macías. 2007. Secondary succession under a slash-and-burn regime in a tropical montane cloud forest: soil and vegetation characteristics. Pages 158-180 in A. C. Newton, editor. Biodiversity loss and conservation in fragmented forest landscapes. The forests of montane Mexico and temperate South America. CABI, Wallingford, Oxfordshire, UK.

Díaz, I., C. Papic, and J. J. Armesto. 1999. An assessment of postdispersal seed predation in temperate rain forest fragments in Chiloé Island, Chile. Oikos 87:228-238.

Dinerstein, E., D. Olson, D. Graham, A. Webster, S. Primm, M. Bookbinder, and G. Ledec. 1995. A conservation assessment of the terrestrial ecoregions of Latin America and the Caribbean. World Wildlife Fund and World Bank, Washington, D.C., USA.

Echeverría, C., D. Coomes, J. Salas, J. M. ReyBenayas, A. Lara, and A. C. Newton. 2006. Rapid fragmentation and deforestation of Chilean temperate forests. Biological Conservation 130:481494.

Echeverría, C., L. Cayuela, R. H. Manson, D. A. Coomes, A. Lara, J. M. Rey-Benayas, and A. C. Newton. 2007a. Spatial and temporal patterns of forest loss and fragmentation in Mexico and Chile. Pages 14-42 in A. C. Newton, editor. Biodiversity loss and conservation in fragmented forest landscapes. The forests of montane Mexico and temperate South America. CABI, Wallingford, Oxfordshire, UK.

Echeverría, C., A. C. Newton, A. Lara, J. M. ReyBenayas, and D. Coomes. 2007b. Impacts of forest fragmentation on species composition and forest structure in the temperate landscape of southern Chile. Global Ecology and Biogeography 16:426439.

Echeverría, C., D. Coomes, M. Hall, and A. C. 
Newton. 2008. Spatially explicit models to analyze forest loss and fragmentation between 1976 and 2020 in southern Chile. Ecological Modelling, in press.

Food and Agriculture Organization (FAO). 2006. The global forest resources assessment. FAO, Rome, Italy.

Fall, A., M. J. Fortin, D. D. Kneeshaw, S. H. Yamasaki, C. Messier, L. Bouthillier, and S. Smyth. 2004. Consequences of various landscapescale ecosystem management strategies and fire cycles on age-class structure and harvest in boreal forests. Canadian Journal of Forest Research 34:310-322.

Galindo-Jaimes, L., M. González-Espinosa, P. Quintana-Ascencio, and L. García-Barrios. 2002. Tree composition and structure in disturbed stands with varying dominance by Pinus spp. in the highlands of Chiapas, México. Plant Ecology 162:259-272.

Golicher, J. D. 2001. The dynamics of disturbed Mexican pine-oak forest: a modelling approach. Dissertation, University of Edinburgh, Edinburgh, UK.

Golicher, D., and A. C. Newton. 2007. Applying succession models to the conservation of tropical montane forest. Pages 200-222 in A. C. Newton, editor. Biodiversity loss and conservation in fragmented forest landscapes. The forests of montane Mexico and temperate South America. CABI, Wallingford, Oxfordshire, UK.

González-Espinosa, M., N. Ramírez-Marcial, A. C. Newton, J. M. Rey-Benayas, A. CamachoCruz, J. J. Armesto, A. Lara, A. Premoli, G. Williams-Linera, A. Altamirano, C. AlvarezAquino, M. Cortés, C. Echeverría, L. GalindoJaimes, M. A. Muñiz, M. C. Núñez-Avila, R. A. Pedraza, A. E. Rovere, C. Smith-Ramírez, O. Thiers, and C. Zamorano. 2007. Restoration of forest ecosystems in fragmented landscapes of temperate and montane tropical Latin America. Pages 335-369 in A. C. Newton, editor. Biodiversity loss and conservation in fragmented forest landscapes. The forests of montane Mexico and temperate South America. CABI, Wallingford, Oxfordshire, UK.

Gustafson, E. J., B. R. Sturtevant, and A. Fall.
2006. A collaborative, iterative approach to transfer modeling technology to land managers. Pages 123134 in A. Perera, L. Buse, and T. Crow, editors. Forest landscape ecology: transferring knowledge to practice. Cambridge University Press, London, UK.

Guzmán-Guzmán, J., and G. Williams-Linera. 2006. Edge effect on acorn removal and oak seedling survival in Mexican lower montane forest fragments. New Forests 31:487-495.

Hamrick, J. L., M. J. W. Godt, and S. L. Sherman-Broyles. 1992. Factors influencing levels of genetic diversity in woody plant species. New Forests 6:95-124.

Harper, K. A., E. S. MacDonald, P. J. Burton, J. Chen, K. D. Brosofske, S. C. Saunders, E. S. Euskirchen, D. Roberts, M. S. Jaiteh, and P.-A. Esseen. 2005. Edge influence on forest structure and composition in fragmented landscapes. Conservation Biology 19:768-782.

Huigen, M. G. A. 2004. First principles of the MameLuke multi-actor modelling framework for land use change, illustrated with a Philippine case study. Journal of Environmental Management 72 (1-2):5-21.

Huth, A., and Ditzer, T. 2001. Long-term impacts of logging in a tropical rain forest - a simulation study. Forest Ecology and Management 142:33-51.

Janssen, M.A., and E. Ostrom. 2006. Empirically based, agent-based models. Ecology and Society 11 (2): 37. [online] URL: http://www.ecologyandsociety. org/vol11/iss2/art37/.

Kammesheidt, L., Köhler, P., and Huth, A. 2002. Simulating logging scenarios in secondary forest embedded in a fragmented neotropical landscape. Forest Ecology and Management 170:89-105.

Köhler, P., and A. Huth. 1998. The effect of tree species grouping in tropical rain forest modelling simulation with the individual based model FORMIND. Ecological Modelling 109:301-321.

Köhler, P., T. Ditzer, R. C. Ong, and A. Huth. 2001. Comparison of measured and modelled growth on permanent plots in Sabahs rain forests. Forest Ecology and Management 144:101-111. 
Lambin, E. F., H. J. Gesit, and E. Lepers. 2003. Dynamics of land-use and land-cover change in tropical regions. Annual Review of Environment and Resources 28: 205-241.

Lambin, E., B. Turner, H. Geist, S. Agbola, A. Angelsen, J. Bruce, O. Coomes, R. Dirzo, G. Fischer, C. Folke, P. S. George, K. Homewood, J. Imbernon, R. Leemans, X. Li, E. Moran, M. Mortimore, P. S. Ramakrishnan, J. F. Richards, H. Skanes, W. Steffen, G. Stone, U. Svedin, T. Veldkamp, C. Vogel, and J. Xu. 2001. The causes of land-cover and land-cover change: moving beyond the myths. Global Environmental Change 11:261-269.

Levin, S. A. 1992. The problem of pattern and scale in ecology: the Robert H. MacArthur award lecture. Ecology 73(6):1943-1967.

Lindenmayer, D. B., and J. F. Franklin. 2002. Conserving forest biodiversity. A comprehensive multiscaled approach. Island Press, Washington, D. C., USA.

López-Barrera, F., and A. C. Newton. 2005. Edge type effect on germination of oak tree species in the Highlands of Chiapas, Mexico. Forest Ecology and Management 217(1):67-79.

López-Barrera, F., A. C. Newton, and R. Manson. 2005. Edge effects in a tropical montane forest mosaic: experimental tests of post-dispersal acorn removal. Ecological Research 20(1):31-40.

López-Barrera, F., R. Manson, M. GonzálezEspinosa, and A. C. Newton. 2006. Effects of the type of montane forest edge on oak seedling establishment along forest-edge-exterior gradients. Forest Ecology and Management 225:234-244.

López-Barrera, F., J. J. Armesto, G. WilliamsLinera, C. Smith-Ramírez, and R. H. Manson. 2007a. Fragmentation and edge effects on plantanimal interactions, ecological processes and biodiversity. Pages 69-101 in A. C. Newton, editor. Biodiversity loss and conservation in fragmented forest landscapes. The forests of montane Mexico and temperate South America. CABI, Wallingford, Oxfordshire, UK.

López-Barrera, F., R. Manson, M. GonzálezEspinosa, and A. C. Newton. 2007b. Effects of varying forest edge permeability on seed dispersal in a neotropical montane forest. Landscape Ecology 22:189-203.

Marshall, E., K. Schreckenberg, and A. C. Newton, editors. 2006. Commercialization of nontimber forest products: factors influencing success. Lessons learned from Mexico and Bolivia and policy implications for decision-makers. UNEP World Conservation Monitoring Centre, Cambridge, UK.

Mathiasen, P., A. E. Rovere, and A. C. Premoli. 2007. Genetic structure and early acting effects of inbreeding in fragmented temperate forests of a selfincompatible tree, Embothrium coccineum. Conservation Biology 21:232-240.

McGarigal, K., S. A. Cushman, M. C. Neel, and E. Ene. 2002. Fragstats: spatial pattern analysis program for categorical maps. Landscape Ecology Program, University of Massachusettts, USA. [online] URL: www.umass.edu/landeco/research/fr agstats/fragstats.html.

Miles, L., A. C. Newton, C. Alvarez-Aquino, J. J. Armesto, R. F. del Castillo, L. Cayuela, C. Echeverría, M. Gonzalez-Espinosa, A. Lara, R. A. Lopez, F. Lopez-Barrera, R. Manson, G. Montoya, M. A. Muñiz, M. Nuñez, R. A. Pedraza, J. M. Rey-Benayas, A. Rovere, N. Rüger, C. Smith, C. Souto, and G. Williams-Linera. 2007. Future scenarios for tropical montane and south temperate forest biodiversity in Latin America. Pages 370-397 in A. C. Newton, editor. Biodiversity loss and conservation in fragmented forest landscapes. The forests of montane Mexico and temperate South America. CABI, Wallingford, Oxfordshire, UK.

Millennium Ecosystem Assessment (MEA). 2005. Ecosystems and human well-being: current state and trends, volume 1. Island Press, Washington, D.C., USA

Myers, N., R. A. Mittermeier, C. G. Mittermeier, G. A. B. da Fonseca, and J. Kent. 2000. Biodiversity hotspots for conservation priorities. Nature 403:853-858.

Naidoo, R., and T. H. Ricketts. 2006. Mapping the economic costs and benefits of conservation. PLoS Biology 4(11):2153-2164.

Newton, A. C. 2007a. Forest ecology and conservation. A handbook of techniques. Oxford 
University Press, Oxford, UK.

Newton, A. C., editor. 2007b. Biodiversity loss and conservation in fragmented forest landscapes. The forests of montane Mexico and temperate South America. CABI, Wallingford, Oxford, UK.

Newton, A. C. 2008a. Restoration of dryland forest in Latin America: the ReForLan project. Ecological Restoration 26(1):10-13.

Newton, A. C. 2008b. Conservation of tree species through sustainable use: how can it be achieved in practice? Oryx 42(2):195-205

Newton, A. C. 2009. Bayesian Belief Networks in environmental modelling: a review of recent progress. Pages 13-50 in P. N. Findlay, editor. Environmental modelling research. Nova Science Publishers, Hauppauge, New York, USA.

Newton, A. C., T. R. Allnutt, W. Dvorak, R. del Castillo, and R. Ennos. 2002. Patterns of genetic variation in Pinus chiapensis, a threatened Mexican pine, detected by RAPD and mitochondrial DNA RFLP markers. Heredity 89:191-198.

Newton, A. C., C. Echeverría, M. GonzálezEspinosa, G. Williams-Linera, N. RamírezMarcial, O. Thiers, J. J. Armesto, J. C. Aravena, and A. Lara. 2007. Testing forest biodiversity indicators by assessing anthropogenic impacts along disturbance gradients. Pages 276-290 in A. C. Newton, editor. Biodiversity loss and conservation in fragmented forest landscapes. The forests of montane Mexico and temperate South America. CABI, Wallingford, Oxfordshire, UK.

Newton, A. C., E. Marshall, K. Schreckenberg, D. Golicher, D. W. Te Velde, F. Edouard, and E. Arancibia. 2006. Use of a Bayesian belief network to predict the impacts of commercializing nontimber forest products on livelihoods. Ecology and Society 11(2): 24. [online] URL: http://www.ecolog yandsociety.org/vol11/iss2/art24/.

Nussbaum, R., and M. Simula. 2005. The forest certification handbook. Earthscan Publications Ltd., London, UK.

Premoli, A. C., C. P. Souto, A. E. Rovere, T. R. Allnut, and A. C. Newton. 2002. Patterns of isozyme variation as indicators of biogeographic history in Pilgerodendron uviferum (D. Don) Florín. Diversity and Distributions 8:57-66.
Premoli, A. C., R.F.del Castillo, A. C. Newton, S. Bekessy, M. Caldiz, C. Martínez-Araneda, P. Mathiasen, M. C. Nuñez-Ávila, P. Quiroga, C. Souto, and S. Trujillo-Argueta. 2007. Patterns of genetic variation in tree species and their implications for conservation. Pages 120-157 in A. C. Newton, editor. Biodiversity loss and conservation in fragmented forest landscapes. The forests of montane Mexico and temperate South America. CABI, Wallingford, Oxfordshire, UK.

Rametsteiner, E., and Simula, M. 2003. Forest certification - an instrument to promote sustainable forest management? Journal of Environmental Management 67:(1)87-98.

Ramírez-Marcial, N., M. González-Espinosa, and G. Williams-Linera. 2001. Anthropogenic disturbance and tree diversity in Montane Rain Forests in Chiapas, Mexico. Forest Ecology and Management 154:311-326.

Rey-Benayas, J. M., L. Cayuela, M. GonzálezEspinosa, C. Echeverría, R. H. Manson, G. Williams-Linera, R.F. Del Castillo, N. RamírezMarcial, M. A. Muñiz-Castro, A. Blanco Macías, A. Lara, and A. C. Newton. 2007 Plant diversity in highly fragmented forest landscapes in Mexico and Chile: implications for conservation. Pages 4368 in A. C. Newton, editor. Biodiversity loss and conservation in fragmented forest landscapes. The forests of montane Mexico and temperate South America. CABI, Wallingford, Oxfordshire, UK.

Ries, L., R. J. Fletcher, J. Battin, and T. D. Sisk. 2004. Ecological responses to habitat edges: mechanisms, models, and variability explained. Annual Review of Ecology, Evolution and Systematics 35:491-522.

Rüger, N. 2006. Dynamics and sustainable use of species-rich moist forests-a process-based modelling approach. Dissertation, University of Osnabrück, Osnabrück, Germany.

Rüger, N., J. J. Armesto, A. G. Gutiérrez, G. Williams-Linera, and A. Huth. 2007a. Processbased modelling of regeneration dynamics and sustainable use in species-rich rainforests Pages 244-275 in A. C. Newton, editor. Biodiversity loss and conservation in fragmented forest landscapes. The forests of montane Mexico and temperate South America. CABI, Wallingford, Oxfordshire, UK. 
Rüger, N., A. G. Guitierrez, W. D. Kissling, J. J. Armesto, and A. Huth 2007b. Ecological impacts of harvesting options for temperate evergreen rain forest in southern Chile - a simulation experiment. Forest Ecology and Management 252(1-3):52-66.

Rüger, N., G. Williams-Linera, W. D. Kissling, W. D. and A. Huth. 2008. Long-term impacts of fuelwood extraction on a Mexican cloud forest. Ecosystems 11:868-881

Rzedowski, J. 1996. Análisis preliminar de la flora vascular de los bosques mesófilos de montaña de México. Acta Botánica Mexicana 35:25-44.

Steininger, M., C. Tucker, P. Ersts, T. Killeen, Z. Villegas, and S. Hecht. 2001. Clearance and fragmentation of tropical deciduous forest in the Tierras Bajas, Santa Cruz, Bolivia. Conservation Biology 15:856-866.

Sturtevant, B. R., A. Fall, D. D. Kneeshaw, N. P. P. Simon, M. J. Papaik, K. Berninger, F. Doyon, D. G. Morgan, and C. Messier. 2007. A toolkit modeling approach for sustainable forest management planning: achieving balance between science and local needs. Ecology and Society 12(2): 7. [online] URL: http://www.ecologyandsociety.org/ vol12/iss $2 /$ art $7 /$.

Sturtevant, B. R., P. A. Zollner, E. J. Gustafson, and D. T. Cleland. 2004. Human influence on fuel connectivity and the risk of catastrophic fire in mixed forests of northern Wisconsin. Landscape Ecology 19:235-253.

Ugalde, L., and Pérez, O. 2001. Mean annual volume increment of selected industrial forest plantation species. Forest Plantation Thematic Papers, Working Paper 1. Forest Resources Development Service, Forest Resources Division, FAO, Rome, Italy.

Urban, D. L., M. F. Acevedo, and S. L. Garman. 1999. Scaling fine-scale processes to large-scale patterns using models derived from models: metamodels. Pages 70-98 in D. J. Mladenoff and W. L. Baker, editors. Advances in spatial modeling of forest landscape change: approaches and applications. Cambridge University Press, Cambridge, UK.

van Gardingen, P. R., M. J. McLeish, P. D. Phillips, D. Fadilah, G. Tyrie, and I. Yasman.
2003. Financial and ecological analysis of management options for logged-over Dipterocarp forests in Indonesian Borneo. Forest Ecology and Management 183:1-29.

Wiersum, K. F. 1995. 200 years of sustainability in forestry: lessons from history. Environmental Management 19(3):321-329.

Wiens, J. A. 1989. Spatial scaling in ecology. Functional Ecology 3(4):385-397.

Williams-Linera, G. 2002. Tree species richness complementarity, disturbance and fragmentation in a Mexican tropical montane cloud forest. Biodiversity and Conservation 11:1825-1843.

Wilson, K., A. Newton, C. Echeverría, C. Weston, and M. Burgman. 2005. A vulnerability analysis of the temperate forests of south central Chile. Biological Conservation 122:9-21.

Wilson, K., and A. C. Newton. 2007. Identification of priority areas for conservation in south central Chile. Pages 314-334 in A. C. Newton, editor. Biodiversity loss and conservation in fragmented forest landscapes. The forests of montane Mexico and temperate South America. CABI, Wallingford, Oxfordshire, UK.

Zavala, M. A., L. Galindo-Jaimes, and M. González-Espinosa. 2007. Models of regional and local stand composition and dynamics of pine-oak forests in the central highlands of Chiapas (Mexico): theoretical and management implications. Pages 223-243 in A. C. Newton, editor. Biodiversity loss and conservation in fragmented forest landscapes. The forests of montane Mexico and temperate South America. CABI, Wallingford, Oxfordshire, UK. 


\section{APPENDIX 1. Study areas}

\section{Study areas}

The research was undertaken within a series of study areas located within highland Mexico and southern South America. Some general information about these locations is provided below. Further information is provided by Newton (2007).

\section{Tropical montane forest}

Neotropical montane forests are widely recognized as being of exceptional conservation importance, being a centre of high diversity and endemicity for many different groups of organisms. For example, some 45,000 plant species are thought to be found in neotropical highlands, nearly a fifth of all species known (Churchill et al. 1995). Cloud forests, being those montane forests in the humid tropics that are frequently covered in clouds or mist, have attracted particular conservation concern. Research focused on montane forests in three areas of Mexico (Fig. A1):

(i) Xalapa, Veracruz. The study area is situated between 1200 and $2000 \mathrm{~m}$ of altitude in the eastern Sierra Madre mountains, and is located between $19^{\circ} 13^{\prime}$ and $19^{\circ} 41^{\prime} \mathrm{N}$, and $96^{\circ} 51^{\prime}$ and $97^{\circ} 01^{\prime} \mathrm{W}$, with an area of $842 \mathrm{~km}^{2}$. Total annual precipitation in this region varies between $1300-2200 \mathrm{~mm}$, while mean annual temperature is between $12-18^{\circ} \mathrm{C}$. Typically, there are three well-defined seasons, the relatively dry-cool season lasting from October-November to March, the dry-warm season during April and May, and the wet-warm season from June to September-October. Soils are andosols. Some important canopy tree species in the study area are Quercus xalapensis, Liquidambar styraciflua, Q. leiophylla and Carpinus caroliniana. Current land cover is a mosaic of cloud forest, secondary forest, coffee plantations, pastures, agricultural crops and human settlements. Most of the land is privately owned.

(ii) Highlands of Chiapas.

The Highlands of central Chiapas is a limestone massif, situated at $16^{\circ} 15^{\prime}-17^{\circ} 10^{\prime} \mathrm{N}$, and $91^{\circ} 45^{\prime}-92^{\circ}$ $50^{\prime} \mathrm{W}$, at altitudes of $1500-2840 \mathrm{~m}$. The climate is temperate sub-humid, with a mean annual temperature of $13-17^{\circ} \mathrm{C}$ and mean annual rainfall typically in the range $1100-1600 \mathrm{~m}$. Soils are a mixture of thin rendzinas, deeper humic acrisols and infertile chromic luvisols. Vegetation includes a number of highly diverse forest formations including seasonal pine and pine-oak forests, montane rain forests $(800-2500 \mathrm{~m}$ elevation) and evergreen cloud forests $(>2500 \mathrm{~m})$. Oaks and pines are usually dominant in the forest canopy, including species such as the oaks Quercus laurina, Q. rugosa and $Q$. crassifolia, and the pines Pinus oocarpa, P. pseudostrobus and P. ayacahuite. The understorey is typically dominated by a diverse shrub community, including species such as Myrcia jurguensenii, Oreopanax xalapensis, Fuchsia spp. and Litsea glaucescens. Most inhabitants belong to Mayan ethnic groups, principally the Tzotzil, Tojolobal and Tzeltal. Land is communally owned. Traditional agriculture involves slash-and-burn ('milpa') involving the cultivation of corn, beans, and squash, producing a landscape mosaic of vegetation at different successional stages.

(iii) El Rincón Alto, Sierra Norte, Oaxaca. The study area is the Sierra Madre de Oaxaca Mountain Range, located in the north of the State of Oaxaca, between the parallels $17^{\circ} 18^{\prime}$ and $17^{\circ} 23^{\prime} \mathrm{N}$ and the meridians $96^{\circ} 15^{\prime}$ and $96^{\circ} 21^{\prime} \mathrm{W}$. The area is part of the El Rincón Alto region and lies at $1850 \pm 150 \mathrm{~m}$ altitude, where tropical montane cloud forest is the primary vegetation. Topography is mountainous and the slopes are usually steep $(15-64 \%)$. The climate is temperate-humid to subhumid, with mean annual temperature ranging between $20-22^{\circ} \mathrm{C}$ and mean precipitation around $1700 \mathrm{~mm} \mathrm{yr}^{-1}$, with a rainy season in summer and a dry season in winter. Soils lie on a bedrock of Mesozoic schist and are classified as entisols, inceptisols and dystrudepts. The land cover is a mosaic of primary forests, secondary forests of different ages after abandonment, and agricultural fields. Successional forests are dominated by the conifer Pinus chiapensis, which occurs in association with other species such as Clethra integerrima, 
Gaultheria acuminata, Liquidambar styraciflua and Phyllonoma laticuspis. Late-successional forests are dominated by broadleaved species such as Persea americana, Quercus spp., Rapanea spp., Ternstroemia hemsleyi and Quetzalia occidentalis. Human population density is relatively low compared to the other Mexican study areas. The area is inhabited by Zapotecs, a native Mexican ethnic group. Land tenure is communal.

South temperate rain forest

Temperate rain forests are distributed along the coastal mountain range of Chile and the main Andean range from $38^{\circ}-56^{\circ} \mathrm{S}$. Within this area, a number of different forest types may be differentiated, including the Valdivian evergreen forests that extend for $250 \mathrm{~km}$ from the Tolten River (4050' S) to south of the Llico River ( $\left.41^{\circ} 30^{\prime} \mathrm{S}\right)$. Notable elements of the flora include the long-lived conifers Monkey puzzle (Araucaria araucana) and alerce (Fitzroya cupressoides), with some trees of the latter species living for more than 3,620 years. Over the past 30 years, the Chilean forestry sector has become a driving force in the national economy, with forest exports increasing from approximately US $\$ 40$ million in 1970 to US\$2.2 billion in 2000. Other main threats to native forests have been the conversion to pasturelands, human-set fires, highgrading (selective felling), fuelwood cutting and other logging practices. Most land is privately owned.

Fig. A-1. Map illustrating the location of the principal study areas, namely Central Veracruz and the Highlands of Chiapas, Mexico, and Rio Maule-Cobquecura (Regions VII and VIII) and Los Muermos (Region X), Chile. Some field-based research was also undertaken in neighboring areas, including Sierra Norte, Oaxaca (Mexico), Chiloé Island (Region X, Chile), locations in Region IX (Chile) and neighboring areas of Argentina.

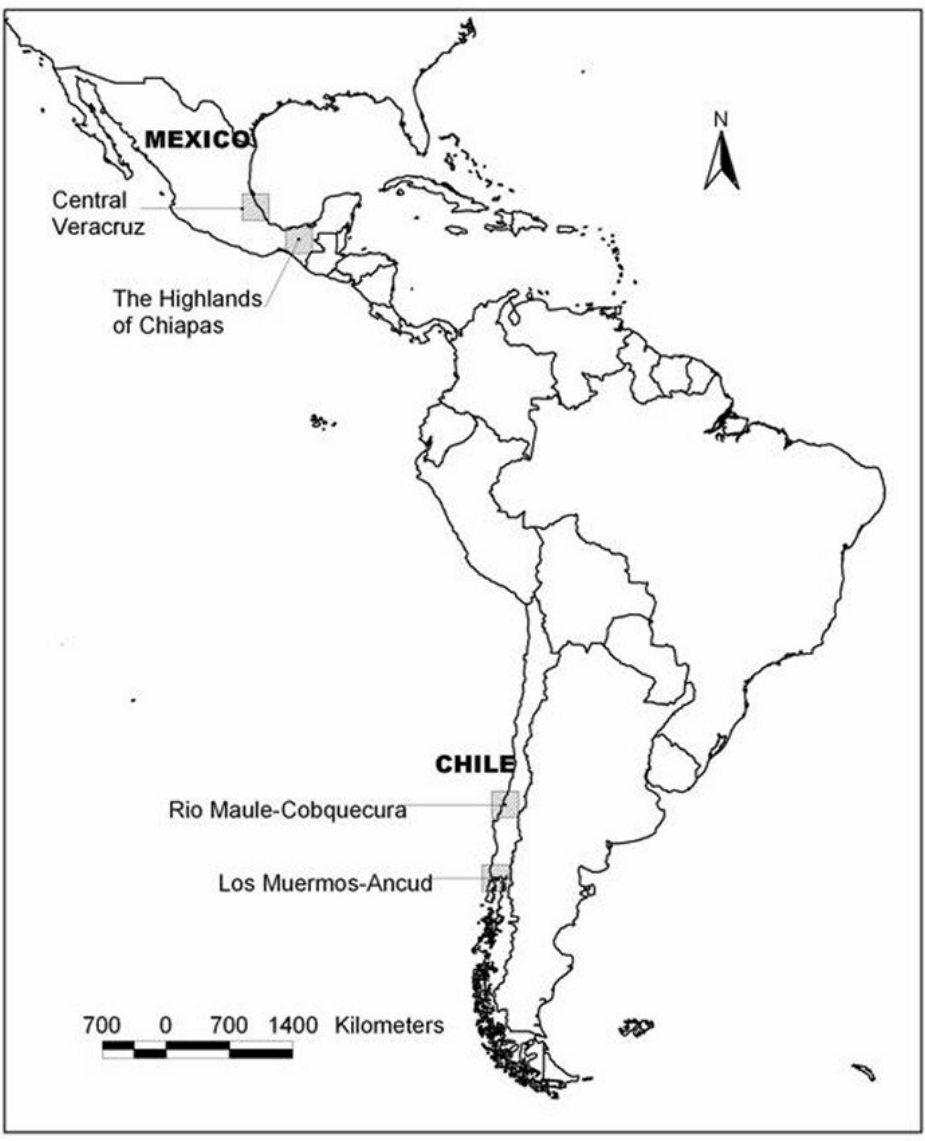


While research activities were distributed throughout southern Chile and adjacent locations in Argentina, investigations were particularly focused on the following three areas of Chile:

\section{(i) Los Muermos area, Region X, Chile.}

The study area corresponds to 503,287 ha located between $41^{\circ} 30 \cdot \mathrm{S}, 73^{\circ} \mathrm{W}$ and $42^{\circ} 20 \cdot \mathrm{S}, 74^{\circ} \mathrm{W}$ in southern Chile. The zone is characterised by a rainy temperate climate with an oceanic influence and without dry-periods, with a mean annual precipitation of around $2000 \mathrm{~mm}$. The landscape is dominated by Valdivian temperate rain forests, surrounded by crops and pasture lands. Many of the remaining forest occur on acidic, shallow, poorly-drained soils referred to as ñadis, which are classified a gleysols. The forests are characterised by the presence of broad-leaved evergreen tree species such as Drimys winteri (Winteraceae), Nothofagus dombeyi (Nothofagaceae), Laurelia philipiana (Monimiaceae), Amomyrtus luma, Amomyrtus meli (both Myrtaceae), and Eucryphia cordifolia (Eucryphiaceae). In some sites, long-lived conifers such as Fitzroya cupressoides and Pilgerodendron uvifera (both Cupressaceae) can also be found. Anthropogenic disturbance has led to early successional stages of the forest being widespread, which are characterized by a high abundance of $D$. winteri and $N$. nitida. In some degraded sites, shrub species such as Berberis spp. (Berberidaceae), Baccharis spp. (Asteraceae), and Gaultheria spp. (Ericaceae) are abundant.

(ii) Chiloé Island, Region X, Chile. The study area comprises about $400 \mathrm{~km}^{2}$ in the north-eastern corner of Chiloé Island, approximately $20 \mathrm{~km}$ north of the city of Ancud (41 $\left.50 \cdot \mathrm{S}, 73^{\circ} 50 \cdot \mathrm{W}\right)$. The landscape is characterized by an undulating topography with altitudes ranging from 50 to $100 \mathrm{~m}$. Soils are generally thin $(<1 \mathrm{~m})$, originating from Pleistocene moraine fields and glacial outwash plains, often with poor drainage. The prevailing climate is described as wet temperate with a strong oceanic influence. Meteorological records at Senda Darwin Biological Station $\left(45^{\circ} 53 \cdot \mathrm{S}, 73^{\circ} 40 \cdot \mathrm{W}\right)$ indicate an annual rainfall of $2,090 \mathrm{~mm}$ and a mean annual temperature of $12^{\circ} \mathrm{C}$. Maximum monthly temperatures (January) are $16^{\circ} \mathrm{C}$ and minimum monthly temperatures (July-August) are $5^{\circ} \mathrm{C}$. Rainfall occurs throughout the year, but $64 \%$ of the precipitation is concentrated from April to September. Lowland forests in the area have been logged since the early 1800s, but land clearing became more intense in the second half of the 20th century. The present-day rural landscape is characterized by a mosaic of remnant forest fragments and grazing pastures. The major forms of human impact on forests during the last century have been selective logging of valuable timber trees, widespread use of fire to clear land for pastures, and increasing forest fragmentation.

The forests are dominated by evergreen, broad-leaved trees, but included narrow-leaf conifers such as Saxegothaea conspicua and Podocarpus nubigena. Floristically, many forests belong to the North Patagonian forest type. Nothofagus nitida, Drimys winteri and Podocarpus nubigena are widespread. Some sites are more typical of a Valdivian rain forest with canopy dominants such as Eucryphia cordifolia, Laureliopsis philippiana and Nothofagus nitida. All forests have an understorey of Myrtaceae trees, often with abundant regeneration of tree seedlings and saplings and abundant cover of the native bamboo Chusquea quila, especially in tree-fall gaps.

(iii) Región del Maule, Chile. This study area covers around 578,164 ha in the Coastal Range of the Maule and Bío-Bío (VII and VIII) regions of south-central Chile, at latitudes between $35^{\circ}$ and $36^{\circ} 30 \cdot \mathrm{S}$ and longitudes between approximately $72^{\circ}$ and $73^{\circ} \mathrm{W}$. The climate is of Mediterranean type, with an average annual rainfall of $700-800 \mathrm{~mm}$ concentrated in the winter; the summers are dry from September to April, with high luminosity. The mean annual temperature is $14^{\circ} \mathrm{C}$. The two main types of soil are well-developed alfisoles, which have evolved from granite substrate; and thinner inceptisoles usually originating from marine sediment rock layers. The natural forest is mainly dominated by secondary forest of Nothofagus species (N. obliqua and N. glauca) (Fagaceae) and sclerophyllous species including Acacia caven (Mimosaceae), Quillaja saponaria (Rosaceae), and Maytenus boaria (Celastraceae). Also, many endangered tree species such as N. alessandri, Pitavia punctata (Rutaceae) and Gomortega keule (Gomortegaceae) occur in the study area. Anthropogenic disturbance is intense: in particular, the region suffered massive forest clearance in the middle of the 20th century for the cultivation of wheat crops, and non-sustainable extraction of firewood in more recent decades. The area therefore currently is characterized by a highly fragmented forest landscape. 


\section{Literature Cited}

Churchill, S.P., Balslev, H., Forero, E. and Luteyn, J. (editors). 1995. Biodiversity and conservation of neotropical montane rain forests: proceedings of the neotropical montane forest biodiversity and conservation symposium. The New York Botanical Garden, New York.

Newton, A. C. (editor). 2007. Biodiversity loss and conservation in fragmented forest landscapes. The forests of montane Mexico and temperate South America. CABI, Wallingford, Oxford. 
APPENDIX 2. Evaluation of modeling approaches

\section{Conceptual models}

Analytical framework for integrating multi-disciplinary research. As noted in the main text, research was underpinned by the development of a conceptual model describing the impacts of human activities on different components of biodiversity, which considered the relationships between different types of anthropogenic disturbance, habitat characteristics and ecological processes at the scale of both landscapes and individual forest patches (Fig. 1). The model was developed at the outset of the research programme, and provided a valuable framework for planning and implementing research activities, as well as guiding both data collection and modelling work. However, the model did not provide a basis for developing an overall integrated model of human impacts on biodiversity, as was initially considered at the outset of the research. This is because of the difficulty of measuring or modelling some of the ecological processes concerned, such as natural selection and dispersal / migration of individuals (although some insight into the latter was provided by molecular marker studies).

The selection of habitat characteristics in the model was very much influenced by spatial metrics emerging from the discipline of landscape ecology, yet in the light of the research results obtained, stand-scale variables such as stand structure and composition also emerged as important indicators of human impacts, and with hindsight should have been explicitly included in the model. The latest phase of the research (the ReForLan project) has therefore developed a new conceptual model to provide an analytical framework for the research, which incorporates these variables (Newton 2008a). In addition, this revised model has been developed according to the DPSIR framework (EEA 1998), to facilitate the identification of suitable indicators for monitoring progress towards SFM objectives (with a particular focus on forest restoration).

Edge effects. In the case of research on edge effects, little progress has been made in developing quantitative models, but two conceptual models have recently been developed (Ries et al. 2004, Harper et al. 2005). Although our research highlighted some limitations in these models, they provided a useful framework for integrating and comparing the results of site-specific studies, and therefore for developing and testing generalisations. As noted by Ries et al. (2004), much work remains to be done regarding the development and rigorous parameterization of models relating to edge responses and their links with conservation management.

Ries et al. (2004) also highlight the fact that limited progress has been made in scaling up edge responses to the landscape scale. Such scaling is required for edge responses to contribute significantly to the development of management and conservation strategies (Sisk and Haddad 2002). Current approaches to scaling up edge responses focus on estimating the distance of edge influence within a patch (the 'core area' model, Laurance and Yensen 1991), or on describing parameters as a function of distance from an edge (the effective area model, Sisk et al. 1997). We employed both of these methods in our research (Echeverría et al. 2007a,b, 2008, Cayuela et al. 2006a,b,c,d). However, neither of these approaches can incorporate variable edge responses relating to landscape-scale interactions such as edge orientation or patch size (Ries et al. 2004).

\section{Genetic variation}

The integration of information on genetic variation with other measures of biodiversity represents a significant challenge. The problem is partly one of scaling: processes influencing genetic variation can operate at a range of scales, from landscapes to individuals, or even individual genes or gene complexes. Understanding of the ecological genetics of tree species is supported by a large body of empirical theory, but as noted here, results obtained for widely distributed north-temperate taxa appear to have limited applicability to species of the geographic areas where our research was undertaken (Premoli et al. 2007). Nevertheless, data from molecular markers can provide valuable information about ecological processes such as dispersal and migration, and helped refine the conceptual understanding of the impacts of forest fragmentation (Newton 2007b). 
One of the limitations of data obtained from molecular markers is that they are usually unrelated to adaptive variation. Ideally, conservation decisions should take account of patterns of adaptive variation, as this is likely to be crucial for the evolutionary viability of populations (Newton 2007a). Little research has been directed towards analysis of adaptive variation in tree species native to the study areas described here, but available data indicate that substantial population differentiation exists (Bekessy et al. 2002; Souto and Premoli 2007). Development of a modelling toolkit for SFM (Sturtevant et al. 2007) might therefore usefully include tools for integrating both quantitative and molecular marker variation with other biodiversity measures.

\section{Statistical models}

Although not explicitly considered by Sturtevant et al. (2007), statistical modeling approaches provide a useful component of a modeling toolkit for SFM. For example, we employed statistical modeling approaches (particularly logistic regression) for analysis of forest loss and fragmentation (Echeverría et al. 2007a,b, Wilson et al. 2005, Cayuela et al. 2006a,c). This enabled the drivers of both forest loss and fragmentation to be identified, and forecasts of potential future land cover change to be developed. A comprehensive analysis of such underlying drivers is required in order to inform future policy decisionmaking and land-use planning, and in order to provide an understanding of the processes of forest loss rather than solely patterns (Bürgi et al. 2004). Here we use the term "drivers" to refer to spatial pattern drivers, or landscape features, that influence where forest loss and fragmentation is likely to occur.

Modeling of land-cover changes such as deforestation requires combining spatially explicit ecological data with information on socio-economic factors. One of the main limitations to this approach is the lack of accurate data on relevant socio-economic variables, although this situation is continually improving within our study areas. A further limitation is that the outputs of statistical regression must be interpreted with caution; many socio-economic and environmental variables are correlated with each other, and the identification of a significant statistical relationship does not necessarily indicate causality between the variables included in the model. A further point is that the output of statistical models can readily be coupled with other models, such as models of forest dynamics at the stand or landscape scale.

\section{SPARs}

In order to evaluate the potential loss of species richness resulting from forest loss and fragmentation, statistical models describing the latter processes were combined with SPARs (Rey Benayas et al. 2007). These represent a form of empirical model, although recently efforts have been made at developing underlying theory (McGill and Collins 2003). SPARs have been widely used for this purpose, but despite their popularity, they suffer from a number of limitations (Sala et al. 2005). Most important of these is the fact that extinctions forecast by such analyses do not occur immediately after a reduction in habitat area. Rather, analyses indicate the number of species that would be expected to go extinct when species numbers reach an equilibrium in a reduced area of habitat (Sala et al. 2005). Evidence suggests that many decades may be required for this equilibrium to be reached (Helm et al. 2006). Furthermore, some species may still be able to survive in an area following conversion of habitat to some other land cover type, making species loss difficult to estimate using this technique (Sala et al. 2005). Another main limitation is that SPARs predict species numbers rather than species composition. It is possible for substantial changes in species composition to occur with little or no change in species richness, yet in conservation terms, it is the species composition that may be of greatest interest (Lindenmayer and Franklin 2002).

\section{Stand dynamics}

Three main approaches have been employed for examining the dynamics of forest stands, as summarized below.

FORMIND was developed in the late 1990s at the University of Kassel, Germany specifically for exploring the dynamics of lowland tropical rain forest. It is now one of the most widely applied models 
for such species-rich forests, having been applied to study the effects of logging, fragmentation, and climate change in Malaysia (Köhler et al. 2001, Köhler and Huth 2004, Huth et al. 2004, 2005), sustainable timber harvesting in Venezuela and Paraguay (Kammesheidt et al. 2001, 2002), and fragmentation effects in French Guyana (Köhler et al. 2003). FORMIND is an individual-oriented forest growth model, which simulates the spatial and temporal dynamics of uneven-aged mixed species forest stands (Kammesheidt et al. 2001, Köhler et al. 2001, 2003).

The following description of the model is based on that presented by Rüger et al. (2007a). FORMIND simulates a forest (in annual time steps) as a mosaic of interacting grid cells with a size of $20 \mathrm{~m} \times 20 \mathrm{~m}$, which is the approximate crown size of a large mature tree. Light availability is the main driver of individual tree growth and forest succession, and within each grid cell all trees compete for light and space following the gap model approach. Each grid cell is divided into horizontal layers for the explicit modelling of the competition for light. The carbon balance of each individual tree is modelled explicitly, including the main physiological processes (photosynthesis, respiration) and litter fall. Growth process equations are modified from the models FORMIX3 and FORMIX3-Q (Ditzer et al. 2000, Huth and Ditzer 2000, 2001). Allometric functions relate above-ground biomass, stem diameter, tree height, crown diameter and stem volume. Tree mortality can occur either through self-thinning in densely populated grid cells, senescence, gap formation by large falling trees, or medium-scale windthrows. Tree regeneration rates are effective rates of recruitment of small trees at a diameter at breast height (dbh) threshold of $1 \mathrm{~cm}$, with seed loss through predation and seedling mortality already being implicitly incorporated. Water and nutrient availability are assumed to be homogeneous and there is no interannual variability of climatic conditions in the model.

While the model was successfully applied to the exploration of forest dynamics in both Chile and Mexico (Rüger et al. 2007a,b; 2008), FORMIND is difficult to parameterise completely, in common with other process-based models of forest dynamics. To cope with high species richness, tree species were grouped into plant functional types according to their maximum height and light demand. While environmental parameters and allometric relations of tree geometry were relatively easy to obtain from field measurements, measurements of physiological parameters were often not available and had to be estimated. Independent field data were used to validate overall model results (Rüger et al. 2007a,b). To improve the data basis for model parameterisation and evaluation it would be desirable to obtain inventory data from larger areas, from secondary forests of different ages, as well as information about mortality rates and the frequency and extent of large-scale disturbances (Rüger et al. 2007a).

$P I N Q U E$ is based on the JABOWA-FORET class of gap models, and was programmed in the opensource R language (see The R Foundation for Statistical Computing, http://www.r-project.org/). The following description is based on that provided by Golicher and Newton (2007). In common with many other individual-based forest stand simulators, the model uses a species specific function that predicts the expected diameter increment for a tree of a given diameter under optimal growth conditions. The model uses fundamental growth equation employed by JABOWA-FORET; modelled individuals do not grow at this optimum, owing to constraints imposed by shading, temperature, water or nutrient availability. In common with other gap models, a simple allometric relationship is used for estimating the shading effect of individual tree canopies. Canopy light transmission is typically calculated using an algorithm that places the trees in order of height within each patch and calculates the leaf area for each tree. Results of field and greenhouse trials were used to produce the assumed growth response of different species with respect to overall light availability. Establishment was based on the proportion of ambient light received at ground level in the model, in relation to the degree of shade tolerance of individual species.

PINQUE represents a simpler type of model than FORMIND, and is correspondingly easier to parameterise. However, once again, a number of assumptions had to be made regarding parameter values because of the lack of detailed ecological and physiological information regarding the tree species occurring in the study area. Despite such uncertainties, model simulations compared well with existing field data, and were used to refine the available empirical theory regarding the dynamics of disturbed montane forest in Mexico (Golicher and Newton 2007). 
Markov model. The dynamical consequences of recruitment patterns for stand dynamics and composition can be easily explored with a Markov model, which assumes that the probability of replacement of one canopy dominant species by other is proportional to the density of juvenile individuals of the latter (Horn 1975). The transition matrix that evaluates the probability of replacement across species combinations is then multiplied by a vector that represents initial stand composition, $t$. The resulting product is another vector representing the expected stand composition at the next generation $t+1$ (the generation time is the time that a tree can remain as a canopy dominant, or maximal age). Field data were used to parameterize a transition matrix for forest stands in Chiapas, and used to explore the successional relationships of forest stands (Zavala et al. 2007). While analytically simple, the results proved useful for understanding the potential impacts of human activities on forest composition (Zavala et al. 2007), providing information complementary to the results of other models of stand dynamics.

The main challenge in using Markov models for exploring stand dynamics relates to the problem of deriving accurate transition probabilities. Ideally, vegetation should be monitored over prolonged periods; such data are not yet available for the study areas considered here. As the probability of transition from any vegetation category to any other category (or state) must be determined, the number of model parameters is a function of the square of the number of categories in the model (Newton 2007a). There is therefore a trade-off between the increased resolution offered by incorporating a larger number of vegetation categories (or states), and the increased difficulty of accurately parameterizing a model with a larger number of transition probabilities. This is particularly problematic given that relatively rare transitions need to be estimated with equivalent precision to relatively common transitions. In addition, Markov models tend to be highly specific to the forest type (and even the particular study area) for which they were created, limiting their practical value. However, it is possible to link Markov or semi-Markov models with gap models enabling the behaviour of the model to be explored at a much larger spatial scale than would have been possible with the gap model alone (Newton 2007a). This is not something that has yet been attempted by our research team.

\section{Landscape dynamics}

A number of different modelling approaches have been employed to examine the spatial dynamics of forest cover at the landscape scale, together with associated biodiversity. To date, modelling activities have primarily focused on use of GEOMOD, but in the latest phase of the research, LANDIS-II is being used to explore the impacts of human activities on forest dynamics (Newton 2008a). In addition, a variety of different approaches are being used to analyse the spatial dynamics of the distribution of individual species, particularly in response to climate change. Brief details of each of these approaches are presented below.

GEOMOD is a GIS-based model, which simulates land-use change by predicting the transition from one land-use state to another. Simulations can be based on both environmental and socio-economic attributes as well as spatial data of forest cover at different time intervals (Hall et al. 1995a,b; Pontius et al. 2001). One of the advantages of GEOMOD is that it requires relatively small amounts of data for calibration and validation compared to other complex dynamic models (Pontius et al. 2001). GEOMOD identifies locations where changes in land uses are most likely by using decision rules based on: (a) the pattern of geophysical variables with respect to already deforested land, (b) stratification by political sub-region, and/or (c) nearest neighbours. This rule simulates the manner in which deforestation occurs on the edges of forest patches, or in open areas of forest fragments (Echeverría et al. 2008). GEOMOD was successfully applied in southern Chile, where it demonstrated high predictive power (Echeverría et al. 2008).

LANDIS-II is based on an object-oriented modelling approach operating on raster GIS maps (He et al. 1999, Mladenoff and He 1999, Scheller et al. 2007). The principal modules of LANDIS relate to forest succession, seed dispersal, wind disturbance, fire and timber harvesting. In LANDIS, each cell is a spatial object containing species, environment, disturbance, and harvesting information (Mladenoff and 
He 1999). Tree species are simulated as the presence or absence of 10-year age cohorts in each cell, rather than as individual trees, greatly reducing the processing power required to perform simulations over large areas. The integration of LANDIS with GIS provides a powerful set of tools with which to explore the potential impacts of management interventions at the landscape scale, which have been used in an increasing number of forest communities in different parts of the world (Mladenoff 2004). The latest version (LANDIS-II) represents a significant development, as the model was re-engineered as an integrated modeling environment, allowing greater flexibility through the use of customized extensions for landscape disturbance and succession, among others (Sturtevant et al. 2007). The main limitation of LANDIS is perhaps its relatively simplistic representation of cohorts (Newton 2007a). We are currently parameterising LANDIS-II for four areas of in Latin America, to explore the potential impacts of fire, livestock grazing and cutting on the spatial dynamics of dry forest, and to examine the potential for forest recovery under different land management scenarios (Newton 2008a). Integration of LANDIS-II with GIS offers ready scope for exchange of spatial data with other modelling tools, such as spatial MCA.

Habitat models. Understanding what constitutes suitable habitat for a particular species is of critical importance to conservation management and planning, yet the specific habitat requirements of many species are poorly understood. Forest managers typically require habitat maps to support management decisions, and such maps may also be required at regional or national scales to inform conservation planning. A range of analytical techniques are now available for building spatial models of species distributions (Elith and Burgman 2003, Guisan and Zimmerman 2000). A number of these are being employed in our current research, including DOMAIN (Carpenter et al. 1993) and MaxEnt (Phillips et al. 2006).

\section{PVA}

Matrix models have been widely used to explore the population dynamics of individual tree species, and provide a valuable tool for exploring harvesting impacts (Newton 2007a). However, complete parameterization of a matrix model may often be very difficult to achieve. For example, accurate estimates of mortality rates may be very difficult to obtain for long-lived tree species, and the influence of density dependence is also often difficult to evaluate (Newton 2007a). Potentially the output of such models can be input to other probabilistic models, such as BBNs (Newton 2009), although this has not yet been attempted for tree species. BBNs have however proved useful for integrating socio-economic information relating to the use of tree species (Newton et al. 2006), an approach that has helped identify some recommendations regarding how the sustainable use of tree species can be achieved in practice (Newton 2008b).

\section{Decision-support tools}

Three analytical approaches are briefly described here, which we are using to integrate research results (including output from other models) in ways that can be used to support decision-making.

Bayesian Belief Network (BBN). A Bayesian Belief Network (sometimes referred to as a Bayesian network or Belief net) may be defined as a graphical model that incorporates probabilistic relationships among variables of interest. The term graphical model is used because the BBN can be represented in the form of a network diagram, to provide a visual representation of the components and dependencies of a domain. Bayesian networks evolved in the late 1980s through developments of theory developed for graphical models, particularly through the work of Pearl (1986, 1988, 1995). This research established BBNs at the interface between statistics, applied artificial intelligence and expert system development. In common with other Bayesian approaches, BBNs can be considered as tools for updating existing ( $a$ priori) information using probabilities as a measure of uncertainty. BBNs may be used as tools for building predictive models, for structuring knowledge or beliefs relating to a domain, or for supporting decision making. The application of BBNs to forest management began in the early 1990s, with Haas (1991) providing an early example. 
BBNs differ from most other approaches to environmental modelling by exclusively using probabilistic, rather than deterministic, expressions to describe the relationships among variables, a feature that is particularly useful in the context of risk assessment and for supporting decision making (Borsuk et al. 2004). A BBN represents a description of the probabilistic relationships among the domain's variables, enabling the joint (or total) probability distribution of all variables to be divided into a series of conditional and unconditional distributions (Borsuk et al. 2004). The graphical nature of the network facilitates visualization of such relationships, and can foster communication among scientists, decisionmakers and other stakeholders regarding the relationships between variables in a particular domain.

BBN models do not necessarily replace existing environmental, economic or social models; instead it is possible to take the outputs from such models and incorporate them in BBNs, by converting them into probability distributions. BBNs can therefore be seen as tools for integrating different kinds of knowledge or evidence, including model outputs and quantitative data, together with subjective information such as expert knowledge. In the context of developing a modelling toolkit for SFM, they may have particular value for meta-modelling. The ability to integrate both qualitative and quantitative information is widely considered to be one of the main assets of BBNs, and is particularly welcomed by researchers investigating environmental management, who may often be required to integrate socioeconomic with biophysical information.

Further information on the use of BBNs in environmental modelling is provided by Newton et al. (2006) and Newton (2009).

Spatial multi-criteria analysis (MCA). This technique offers a tool for exploring spatial data (integrated with GIS) in relation to decision-making. The approach is particularly well suited to participatory research approaches, as it enables the views of different stakeholders to be integrated and explored. Analyses are typically based on use of the analytical hierarchy process (AHP) and its extensions into the spatial domain. This approach involves the construction of an evaluation matrix, which contains the possible alternatives relating to a particular decision and the criteria against which they will be evaluated. The scores for this matrix can be developed during participatory workshops with stakeholders. The different evaluation criteria are typically characterised by different importance levels, which can vary greatly between stakeholders. This element is included in the analysis by assigning subjective weights to each criterion (prioritisation). A weight can be defined as a value assigned to a criterion that indicates its importance relatively to the other criteria under consideration. Once the weights are assigned, aggregation can be performed using a decision rule that dictates how best to order the alternatives, on the basis of the intrinsic characteristics of the alternatives (criterion scores), and on the preferences of the decision-makers (criterion assessment and weights). Models typically display great sensitivity to these weights, so it is important to adopt a consensual approach in which different weighting systems are evaluated, each representing a contrasting perspective on the decision problem. The sensitivity of a particular decision to the weights and values elicited from stakeholders can be explored in the analysis.

Use of spatial data enables this technique to be integrated with other modelling approaches. For example, the ReForLan project (Newton 2008a) is employing spatial MCA to explore options for forest restoration in collaboration with stakeholders. Outputs of other spatially explicit models, such as LANDIS-II, could potentially be used as input, enabling (for example) the location of management interventions to be explored under different scenarios of environmental change. Further details of spatial MCA approaches are provided by Geneletti (2004) and Kangas et al. (2000).

Scenarios. All ecological models are based on a range of assumptions and uncertainties. Scenario planning offers a framework for developing environmental management approaches under such uncertain conditions. A scenario can be defined in this context is an account of a plausible future (Peterson et al. 2003). The development of scenarios is a recognized tool in business planning and economic forecasting, but only recently has it been applied to conservation. Peterson et al. (2003) provide a valuable introduction to the use of scenarios in a conservation context. Further information on the technique is provided by Newton (2007a). 
Scenario planning provides a tool to explore the uncertainty surrounding the future consequences of a decision, by developing a small number of contrasting scenarios. Generally scenarios are developed by a range of stakeholders in a systemic process of collecting, discussing and analysing information, through a series of workshops. The technique therefore seems highly relevant to the participatory modelling approach described by Sturtevant et al. (2007). Scenarios may draw upon a variety of quantitative and qualitative information, such as the results of ecological surveys and outputs from modelling exercises. Peterson et al. (2003) suggest that the major benefits of using scenario planning for conservation are (i) increased understanding of key uncertainties, (ii) incorporation of alternative perspectives into conservation planning, and (iii) greater resilience of decisions to surprise. However, the use of this technique to support SFM is in its infancy.

\section{Literature Cited}

Bekessy, S. A., D. Sleep, A. Stott, M. Menuccini, P. Thomas, R. A. Ennos, M. A. Burgman, M. F. Gardner, and A. C. Newton. 2002. Adaptation of Monkey Puzzle to arid environments reflected by regional differences in stable carbon isotope ratio and allocation to root biomass. Forest Genetics 9(1): 63-70.

Borsuk, M. E., C. A. Stow, and K. H. Reckhow. 2004. A Bayesian network of eutrophication models for synthesis, prediction, and uncertainty analysis. Ecological Modelling 173(2-3): 219-239.

Bürgi, M., A. M. Hersperger, and N. Schneeberger. 2004. Driving forces of landscape changecurrent and new directions. Landscape Ecology 19: 857-868.

G. Carpenter, A.N. Gillison., and J. Winter 1993. DOMAIN: a flexible modelling procedure for mapping potential distributions of plants and animals. Biodiversity and Conservation 2: 667-680.

Cayuela L., D. J. Golicher, and J. M. Rey-Benayas. 2006a. The extent, distribution and fragmentation of vanishing montane cloud forest in the Highlands of Chiapas, Mexico. Biotropica 38(4): 544-554.

Cayuela, L., D. J. Golicher, J. M. Rey-Benayas, M. González-Espinosa, and N. Ramírez-Marcial. 2006b. Fragmentation, disturbance and tree diversity conservation in tropical montane forests. Journal of Applied Ecology 43: 1172-1182.

Cayuela, L, J. M. Rey Benayas, C. Echeverría. 2006c. Clearance and fragmentation of tropical montane forests in the Highlands of Chiapas, Mexico (1975-2000). Forest Ecology and Management 226: $208-218$.

Cayuela, L., J. M. Rey Benayas, A. Justel, J. Salas-Rey. 2006d. Modelling tree diversity in a highly fragmented tropical montane landscape. Global Ecology and Biogeography 15: 602-613.

Ditzer, T., R. Glauner, M. Förster, P. Köhler, and A. Huth. 2000. The process-based stand growth model FORMIX3-Q applied in a GIS environment for growth and yield analysis in a tropical rain forest. Tree Physiology 20:367-381.

Echeverría, C., L. Cayuela, R. H. Manson, D. A. Coomes, A. Lara, J. M. Rey-Benayas, and A. C. Newton. 2007a. Spatial and temporal patterns of forest loss and fragmentation in Mexico and Chile. Pages 14-42 in A. C. Newton, editor. Biodiversity loss and conservation in fragmented forest landscapes. The forests of montane Mexico and temperate South America. CABI, Wallingford, Oxfordshire, UK.

Echeverría, C., A. C. Newton, A. Lara, J. M. Rey-Benayas, and D. Coomes. 2007b. Impacts of forest fragmentation on species composition and forest structure in the temperate landscape of southern Chile. Global Ecology and Biogeography 16: 426-439. 
Echeverría, C., D. Coomes, M. Hall, and A. C. Newton. 2008. Spatially explicit models to analyze forest loss and fragmentation between 1976 and 2020 in southern Chile. Ecological Modelling, in press.

EEA. 1998. Europe's Environment - The $2^{\text {nd }}$ Assessment. Office for Publications of the European Communities, European Environment Agency.

Elith, J., and M. A. Burgman. 2003. Habitat models for population viability analysis. Pages 203-235 in C. A. Brigham, and M. A. Schwartz, editors. Population viability in plants. Conservation, management and modeling of rare plants. Ecological Studies 165, Springer-Verlag, Berlin.

Geneletti, D. 2004. A GIS-based decision support system to identify nature conservation priorities in an alpine valley. Land Use Policy 21:149-160.

Golicher, D., and A. C. Newton. 2007. Applying succession models to the conservation of tropical montane forest. Pages 200-222 in A. C. Newton, editor. Biodiversity loss and conservation in fragmented forest landscapes. The forests of montane Mexico and temperate South America. CABI, Wallingford, Oxfordshire, UK.

Guisan, A. and N. E. Zimmermann. 2000. Predictive habitat distribution models in ecology. Ecological Modelling 135:47-186.

Haas, T. C. 1991. A Bayesian Belief Network advisory system for aspen regeneration. Forest Science 37(2):627-654.

Hall, C. A. S., H. Tian, Y. Qi., G. Pontius, J. Cornell, and J. Uhlig. 1995a. Spatially explicit models of land use change and their application to the tropics. DOE Research Summary, No. 31. CDIAC, Oak Ridge National Laboratory, Tennessee.

Hall, C. A. S., H. Tian, Y. Qi., G. Pontius, J. Cornell, and J. Uhlig. 1995b. Modeling spatial and temporal patterns of tropical land use change. Journal of Biogeography 22: 753-757.

Harper, K. A., E. S. MacDonald, P. J. Burton, J. Chen, K. D. Brosofske, S. C. Saunders, E. S. Euskirchen, D. Roberts, M. S. Jaiteh, and P-A. Esseen. 2005. Edge influence on forest structure and composition in fragmented landscapes. Conservation Biology 19: 768-782.

He, H.S., D. J. Mladenoff and J. Boeder. 1999. Object-oriented design of LANDIS, a spatially explicit and stochastic landscape model. Ecological Modelling 119: 1-19.

Helm, A., I. Hanski, and M. Pärtel. 2006. Slow response of plant species richness to habitat loss and fragmentation. Ecology Letters 9:72-77.

Horn, H. 1975. Markovian properties of forest succession. Pages 196-211 in M. L. Cody, and J. Diamond, editors. Ecology and Evolution of Communities. Belknap Press, Cambridge, USA.

Huth, A., M. Drechsler, and P. Köhler. 2004. Multicriteria evaluation of simulated logging scenarios in a tropical rain forest. Journal of Environmental Management 71: 321-333.

Huth, A., M. Drechsler, and P. Köhler. 2005. Using multicriteria decision analysis and a forest growth model to assess impacts of tree harvesting in Dipterocarp lowland rain forests. Forest Ecology and Management 207:215-232.

Huth, A., and T. Ditzer. 2000. Simulation of the growth of a lowland Dipterocarp rain forest with FORMIX3. Ecological Modelling 134:1-25. 
Huth, A., and T. Ditzer. 2001. Long-term impacts of logging in a tropical rain forest - A simulation study. Forest Ecology and Management 142:33-51.

Kammesheidt, L., P. Köhler and A. Huth. 2001. Sustainable timber harvesting in Venezuela: A modelling approach. Journal of Applied Ecology 38:756-770.

Kammesheidt, L., P. Köhler, and A. Huth. 2002. Simulating logging scenarios in secondary forest embedded in a fragmented neotropical landscape. Forest Ecology and Management 170:89-105.

Kangas, J., R. Store, P. Leskinen, and L. Mehtatalo. 2000. Improving the quality of landscape ecological forest planning by utilising advanced decision-support tools. Forest Ecology and Management 132:157-171.

Köhler, P., J. Chave, B. Riera, and A. Huth. 2003. Simulating long-term response of tropical wet forests to fragmentation. Ecosystems 6:114-128.

Köhler, P., T. Ditzer, R. C. Ong, and A. Huth. 2001. Comparison of measured and modelled growth on permanent plots in Sabahs rain forests. Forest Ecology and Management 144:101-111.

Köhler, P., and A. Huth. 2004. Simulating growth dynamics in a South-East Asian rain forest threatened by recruitment shortage and tree harvesting. Climatic Change 67:95-117.

Laurance, W. F. and E. Yensen. 1991. Predicting the impacts of edge effects in fragmented habitats. Biological Conservation 55:77-92.

Lindenmayer, D. B., and J. F. Franklin. 2002. Conserving forest biodiversity. A comprehensive multiscaled approach. Island Press, Washington DC.

McGill, B., and C. Collins. 2003. A unified theory for macroecology based on spatial patterns of abundance. Evolutionary Ecology Research 5:469-492.

Mladenoff, D. J. 2004. Landis and forest landscape models. Ecological Modelling 180:7-19.

Mladenoff, D. J., and H. S. He. 1999. Design and behavior of LANDIS, an object-oriented model of forest landscape disturbance and succession. Pages 125-162 in D. J. Mladenoff and W. L. Baker, editors. Spatial Modelling of Forest Landscape Change: Approaches and Applications. Cambridge University Press, Cambridge, UK.

Newton, A. C. 2007a. Forest ecology and conservation. A handbook of techniques. Oxford University Press, Oxford.

Newton, A. C. (editor) 2007b. Biodiversity loss and conservation in fragmented forest landscapes. The forests of montane Mexico and temperate South America. CABI, Wallingford, Oxford, UK.

Newton, A. C. 2008a. Restoration of dryland forest in Latin America: the ReForLan project. Ecological Restoration 26(1):10-13.

Newton, A. C. 2008b. Conservation of tree species through sustainable use: how can it be achieved in practice? Oryx 42(2):195-205.

Newton, A. C. 2009. Bayesian Belief Networks in environmental modelling: a review of recent progress. In: P. N. Findlay, editor. Environmental modelling research. Nova Science Publishers, Hauppauge, New York. 
Newton, A. C., E. Marshall, K. Schreckenberg, D. Golicher, D. W. Te Velde, F. Edouard, and E. Arancibia 2006. Use of a Bayesian Belief Network to predict the impacts of commercializing nontimber forest products on livelihoods. Ecology and Society 11(2): 24. [online] URL: http://www. ecologyandsociety.org/vol11/iss2/art24/

Pearl, J. 1986. Fusion, propagation and structuring in belief networks. Artificial Intelligence 29:241-288.

Pearl, J. 1988. Probabilistic reasoning in intelligent systems: networks of plausible inference. Morgan Kaufmann Publishers, Inc., Mateo, California, USA.

Pearl, J. 1995. Causal diagrams for empirical research. Biometrika 82(4): 669-688.

Peterson, G. D., G. S. Cumming, and S. R. Carpenter. 2003. Scenario planning: a tool for conservation in an uncertain world. Conservation Biology 17(2): 358-366.

Phillips, S. J., R. P. Anderson, and R. E. Schapire. 2006. Maximum entropy modeling of species geographic distributions. Ecological Modelling 190:231-259.

Pontius, R. G., J. Cornell, and C. Hall. 2001. Modelling the spatial pattern of land-use change with GEOMOD2: application and validation for Costa Rica. Agriculture Ecosystems and the Environment 85:191-203.

Premoli, A. C., R.F.del Castillo, A. C. Newton, S. Bekessy, M. Caldiz, C. Martínez-Araneda, P. Mathiasen, M. C. Nuñez-Ávila, P. Quiroga, C. Souto, and S. Trujillo-Argueta. 2007. Patterns of genetic variation in tree species and their implications for conservation. Pages 120-157 in A. C. Newton, editor. Biodiversity loss and conservation in fragmented forest landscapes. The forests of montane Mexico and temperate South America. CABI, Wallingford, Oxfordshire, UK.

Rey-Benayas, J. M., L. Cayuela, M. González-Espinosa, C. Echeverría, R. H. Manson, G. Williams-Linera, R.F. Del Castillo, N. Ramírez-Marcial, M. A. Muñiz-Castro, A. Blanco Macías, A. Lara, and A. C. Newton. 2007 Plant diversity in highly fragmented forest landscapes in Mexico and Chile: implications for conservation. Pages 43-68 in A. C. Newton, editor. Biodiversity loss and conservation in fragmented forest landscapes. The forests of montane Mexico and temperate South America. CABI, Wallingford, Oxfordshire, UK.

Ries, L., R. J. Fletcher, J. Battin, T. D. Sisk. 2004. Ecological responses to habitat edges: mechanisms, models, and variability explained. Annual Review of Ecology, Evolution and Systematics 35: 491-522.

Rüger, N., J. J. Armesto, A. G. Gutiérrez, G. Williams-Linera, and A. Huth. 2007a. Process-based modelling of regeneration dynamics and sustainable use in species-rich rainforests Pages 244-275 in A. C. Newton, editor. Biodiversity loss and conservation in fragmented forest landscapes. The forests of montane Mexico and temperate South America. CABI, Wallingford, Oxfordshire, UK.

Rüger, N., A. G. Guitierrez, W. D. Kissling, J. J. Armesto and A. Huth 2007b. Ecological impacts of harvesting options for temperate evergreen rain forest in southern Chile - a simulation experiment. Forest Ecology and Management 252(1-3): 52-66.

Rüger, N., G. Williams-Linera, W.D. Kissling, W.D. and A. Huth. 2008. Long-term impacts of fuelwood extraction on a Mexican cloud forest. Ecosystems 11: 868-881

Sala, O. E., D. van Vuuren, H. M. Pereira, D. Lodge, J. Alder, G. Cumming, A. Dobson, V. Wolters, M. A. Xenopoulos. 2005. Biodiversity across scenarios. Pages 375-408 in S. R. Carpenter, P. L. Pingali, E. M. Bennett, and M. B. Zurek, editors. Ecosystems and human well-being: scenarios, volume 2. 
Millennium Ecosystem Assessment Series. Island Press, Washington DC.

Scheller, R. M., J. B. Domingo, B. R. Sturtevant, J. S. Williams, A. Rudy, E. J. Gustafson, and D. J. Mladenoff. 2007. Design, development, and application of LANDIS-II, a spatial landscape simulation model with flexible temporal and spatial resolution. Ecological Modelling 201:409-419.

Segura, G. 2000. Mexico's forest sector and policies: a general perspective. Constituting the Commons: Crafting Sustainable Commons in the New Millenium, the Eighth Conference of the International Association for the Study of Common Property, Bloomington, Indiana, USA, May 31-June 4. http://dlc. dlib.indiana.edu/archive/00000341/

Sisk, T. D., and N. M. Haddad. 2002. Incorporating the effects of habitat edges into landscape models: effective area models for cross-boundary management. Pages 208-40 in J. Liu and W. Taylor, editors, Integrating Landscape Ecology into Natural Resource Management.: Cambridge University Press, Cambridge, UK.

Sisk, T. D., N. M. Haddad, and P. R. Ehrlich. 1997. Bird assemblages in patchy woodlands: modeling the effects of edge and matrix habitats. Ecological Applications 7:1170-80.

Souto, C. P., and A. C. Premoli. 2007. Geographic variation in leaf traits of the widespread Proteaceae Embothrium coccineum reflect habitat heterogeneity in Patagonia. Journal of Biogeography, in press.

Sturtevant, B. R., A. Fall, D. D. Kneeshaw, N. P. P. Simon, M. J. Papaik, K. Berninger, F. Doyon, D. G. Morgan, and C. Messier. 2007. A toolkit modeling approach for sustainable forest management planning: achieving balance between science and local needs. Ecology and Society 12(2):7. [online] URL: http://www.ecologyandsociety.org/vol12/iss2/art7/

Wilson, K., A. Newton, C. Echeverría, C. Weston, and M. Burgman. 2005. A vulnerability analysis of the temperate forests of south central Chile. Biological Conservation 122:9-21.

Zavala, M. A., L. Galindo-Jaimes, and M. González-Espinosa. 2007. Models of regional and local stand composition and dynamics of pine-oak forests in the central highlands of Chiapas (Mexico): theoretical and management implications. Pages 223-243 in A. C. Newton, editor. Biodiversity loss and conservation in fragmented forest landscapes. The forests of montane Mexico and temperate South America. CABI, Wallingford, Oxfordshire, UK. 


\section{APPENDIX 3. Toward sustainable forest management in Mexico and Chile}

As noted in the main text, the research described here was designed to support the sustainable forest management (SFM) in the study areas. Following Nussbaum and Simula (2005), the research considered SFM to represent a form of integrated land-use planning. In this respect, the concept of SFM extends beyond the sustainable management of individual forest stands to embrace the sustainable management of forested landscapes, including spatial attributes such as the size and connectivity of forest patches. The principal focus of the research was maintenance of forest biodiversity, which is widely acknowledged to represent one element of SFM approaches. A comprehensive treatment of SFM would encompass other environmental aspects, such as maintenance of soil fertility and water quality, as well as social and economic issues (Nussbaum and Simula 2005). The research presented here therefore only represents a partial contribution to the development of SFM approaches in the study areas. Development of a comprehensive approach would require further development of the 'toolkit' employed to date, to include these other elements.

One of the key findings of the current research was that current approaches to land use are not sustainable in any of the study areas. Livestock grazing, use of fire, and harvesting of trees for timber and fuelwood were widespread throughout the study areas, and are responsible for widespread forest loss and degradation. Additional threats to native forests were specific to particular study areas, such as the establishment of plantations of exotic tree species in Chile and shifting cultivation in parts of Mexico. The tools employed by the research enabled substantial impacts of such human activities to be identified, on the spatial characteristics of forest landscapes, the structure and composition of forest stands, and elements of biodiversity including species richness and genetic variation. These impacts were documented through the implementation of specific research themes (Figure 2), designed to address the ecological processes identified in the underlying analytical framework (Figure 1), through use of different elements of the toolkit.

Research also examined the process of forest recovery following disturbance, through the analysis of successional chronosequences and disturbance gradients, and through exploration of models of forest dynamics. Results highlighted the low rate of recovery in all of the forest communities examined, indicating that timescales of centuries would be required to re-establish the characteristics of old-growth native forest. These findings were consistent with the result of field observations, indicating that current land use approaches are leading to the progressive elimination of forest with old-growth characteristics from the landscapes studied. In particular, this involves the loss of large, shade-tolerant, latesuccessional trees and the species that they support.

Implementation of SFM approaches therefore needs to involve development of a sustainable land use strategy, to ensure that the biodiversity associated with native forests is maintained. Three potential response options could form elements of such an SFM approach, namely forest protection, restoration or sustainable use. As the research focused on forest landscapes situation outside protected areas, the 'protection' option received relatively little attention. Forest restoration is a highly novel approach for the study areas examined; many of the actions undertaken during this research initiative represented the first attempts to restore the forest types concerned. Here the future challenge is to extend restoration activities beyond the scale of experimental studies, towards the restoration of forest landscapes, an approach being explored in current research (Newton 2008b). Large-scale forest restoration efforts may result in significant costs to landowners and other stakeholders, and therefore the analysis of the potential costs and benefits of forest restoration is a research priority, to enable cost-effective restoration priorities to be identified. The toolkit is therefore currently being extended to include tools for mapping and valuing the ecosystem services provided by forests to human communities, together with the costs of restoration actions. These could then be explored with tools such as spatial multi-criteria analysis, to identify priority areas for restoration to be identified (Newton 2008b).

Research also examined the sustainable harvesting of tree species as a potential response option. In particular, the 'conservation-through-use' approach was examined, as in recent years it has attracted 
widespread interest, particularly in the context of tropical forest conservation (Neumann and Hirsch 2000). This approach is based on the contention that forests can be conserved if rural communities gain some direct economic benefit from harvesting forest products. In the current research, a range of tree species were examined in detail to test the validity of the 'conservation-through-use' approach, supported by the use of population viability modelling (Newton 2008b). Results highlighted that tree species are subjected to a variety of different threats, which often act in combination. For conservation action to be effective, all relevant threats must be addressed. In order for the 'conservation-through-use' approach to be effective, the income derived from sale of forest products should be used to protect the forest against other threats, such as fire, grazing by livestock or conversion to agriculture. Research indicated that this is rarely achieved in practice (Newton 2008b). The development of SFM approaches based on sustainable harvesting will therefore depend on the forest being protected from the many other threats identified during this research. In addition, appropriate silvicultural approaches will need to be identified for the tree species concerned.

In southern Chile, some $55 \%$ of the native forests have been substituted by exotic plantations (Lara et al. 1999), mostly established during the past three decades following the introduction of financial incentives for plantation establishment. In addition, native forests have often been degraded through high-grading, i.e. selective cutting of the largest and best-formed trees. To address this, there have been repeated calls for a new forestry legislation that could foster the sustainable management of remaining native forests. According to the 'conservation-through-use' approach, this could increase their economic value and prevent further loss to other land uses. However, management of evergreen temperate rain forest is considered to be challenging, because of the relatively high structural complexity and tree species richness, and its dependence on biotic interactions for pollination and seed dispersal (Rüger et al. 2007). During recent decades, pilot silvicultural experiments have explored the recovery of evergreen rain forests from timber harvest, and strip-cutting and selective logging have been identified as potential management options (Rüger et al. 2007). However, the design, execution and monitoring of large silvicultural experiments remains costly and operationally difficult. Modelling approaches were therefore employed to assess the long-term consequences of different management options and to provide guidelines for forest managers aiming at reconciling conservation and production objectives (Rüger et al. 2007). The logging strategies that were simulated are either practiced by small forest owners or companies (selective logging) or were suggested to promote the regeneration of lightdemanding species after harvesting (strip-cutting) (Rüger et al. 2007).

In Mexico, in the 1950's a single silvicultural system was mandated by law for any type of forest management in the country, regardless of the characteristics of the forest, which consisted of a polycyclic, selective, diameter-limit harvesting regime (Segura 2000). This resulted in widespread highgrading of native forests. After the mid 1970's the application of silvicultural regimes was deregulated, and a range of different silvicultural methods were introduced in different parts of the country, focusing on even-aged management and natural regeneration. However, the selective cutting system is still being widely used (Segura 2000). Very few native forests in Mexico are currently being managed on a sustainable basis for timber production, at least within the study areas examined by this research. In Mexico, model simulations focused on patch clearfelling, which represents a traditional form of forest use, involving slash-and-burn clearance of patches of around one hectare for timber extraction combined with short-term rotational planting of maize. Additional simulations focused on the clearance of small patches of forest at random intervals of time, a pattern typical of areas that are used by indigenous communities for timber and fuelwood production. This simulation results in a form of "dynamic equilibrium" being established after around twenty five years of succession. Both pines and oaks constantly regenerate under this regime, which allows light to reach the forest floor. Some of the more shade-tolerant broadleaved species can establish under this regime of low level disturbance, providing an external seed source is assumed to exist (Golicher and Newton 2007).

Further modelling activities focused on the extraction of fuelwood, one of the main uses of Mexican montane forests by simulating the potential long-term impacts of repeated harvesting of single trees (Rüger et al. 2008). A wide wide range of possible harvesting scenarios were explored, differing in 
wood volume harvested and preferred tree species and sizes. Results showed that the overall impact on forest structure and community composition increased linearly with the amount of harvested wood volume. Even at low levels of harvesting, forest size structure became more homogeneous in the long term because large old trees disappeared from the forest, but these changes might take decades or even centuries. Although recruitment of harvested species benefited from harvesting, species composition shifted to tree species that are not used for fuelwood. These results could be used to support the design of management strategies for the natural species-rich forests that achieve a balance between economic needs and ecological goals of the stakeholders (Rüger et al. 2008).

These examples illustrate how the toolkit for SFM has been developed to date, and applied to the different study areas. One of the key features of the toolkit approach is its flexibility; different models and other analytical tools can be applied in various combinations to address the specific characteristics and management issues of different study areas. However, development of the toolkit represents a "work in progress'; there remains scope for increased integration of its various elements, for example by further loose-coupling of models. This is being explored in current research, where raster maps of forest loss, fragmentation and condition derived from remote sensing imagery and linked to statistical and rulebased models, are being further coupled with the landscape-scale forest model LANDIS II, spatial MCA approaches and Bayesian Belief Networks (Newton 2008a). Such integration will enable priority areas for different management actions to be identified, to support the development of spatial planning approaches for the selected landscapes. This approach is entirely consistent with the conception of SFM approaches being a form of integrated land-use planning (Nussbaum and Simula 2005), and is designed to support efforts to implement such planning.

\section{Literature Cited}

Golicher, D., and A. C. Newton. 2007. Applying succession models to the conservation of tropical montane forest. Pages 200-222 in A. C. Newton, editor. Biodiversity loss and conservation in fragmented forest landscapes. The forests of montane Mexico and temperate South America. CABI, Wallingford, Oxfordshire, UK.

Lara, A., M. E. Solari, P. Rutherford, O. Thiers, R. Trecaman, R. Molina, A. R. Prieto and C. Montory. 1999. Cobertura de la vegetación original de laEcoregión de los bosques valdivianos en Chile hacia 1550. WWF-Universidad Austral de Chile, Valdivia.

Neumann, R.P. and E. Hirsch. 2000. Commercialization of non-timber forest products: review and analysis of research. CIFOR, Bogor, Indonesia.

Newton, A. C. 2008a. Restoration of dryland forest in Latin America: the ReForLan project. Ecological Restoration 26(1):10-13.

Newton, A. C. 2008b. Conservation of tree species through sustainable use: how can it be achieved in practice? Oryx 42(2):195-205.

Rüger, N., A. G. Guitierrez, W. D. Kissling, J. J. Armesto and A. Huth 2007. Ecological impacts of harvesting options for temperate evergreen rain forest in southern Chile - a simulation experiment. Forest Ecology and Management 252(1-3): 52-66.

Rüger, N., G. Williams-Linera, W.D. Kissling, W.D. and A. Huth. 2008. Long-term impacts of fuelwood extraction on a Mexican cloud forest. Ecosystems 11: 868-881

Segura, G. 2000. Mexico's forest sector and policies: a general perspective. Constituting the Commons: Crafting Sustainable Commons in the New Millenium, the Eighth Conference of the International Association for the Study of Common Property, Bloomington, Indiana, USA, May 31-June 4. http://dlc. dlib.indiana.edu/archive/00000341/. 